\title{
Confronting the Privatization and Commercialization of Academic Research: An Analysis of Social Implications at the Local, National, and Global Levels
}

Risa L. Lieberwitz

Cornell University

Follow this and additional works at: https://www.repository.law.indiana.edu/ijgls

Part of the Education Law Commons, International Law Commons, and the Legal Education

Commons

\section{Recommended Citation}

Lieberwitz, Risa L. (2005) "Confronting the Privatization and Commercialization of Academic Research: An Analysis of Social Implications at the Local, National, and Global Levels," Indiana Journal of Global Legal Studies: Vol. 12 : Iss. 1 , Article 4.

Available at: https://www.repository.law.indiana.edu/ijgls/vol12/iss1/4

This Symposium is brought to you for free and open access by the Law School Journals at Digital Repository @ Maurer Law. It has been accepted for inclusion in Indiana Journal of Global Legal Studies by an authorized editor of Digital Repository @ Maurer Law. For more information, please contact rvaughan@indiana.edu.

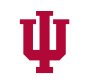

JEROME HALL LAW LIBRARY

INDIANA UNIVERSITY

Maurer School of Law
Blooming ton 


\title{
Confronting the Privatization and Commercialization of Academic Research: An Analysis of Social Implications at the Local, National, and Global Levels
}

\author{
Risa L. Lieberwitz*
}

INTRODUCTION

In the current era of capitalist hegemony, the term "globalization" has become synonymous with the global dominance of private market economies. Though concepts of "internationalism" have long been associated with the political Left, the possibilities of a progressive vision of globalization are currently overshadowed by the deepening of private market policies in existing capitalist economies and the expansion of capitalism to former socialist countries and to developing countries throughout the world. This phenomenon has affected all societal institutions through governmental implementation of privatization policies and deregulation; through the power of global financial institutions - such as the World Bank and the International Monetary Fund - to impose loan conditions that require governments to adopt policies that promote private markets; ${ }^{1}$ and through multilateral trade agreements that favor transnational corporations (TNCs) in their pursuit of increased capital mobility and market expansion. ${ }^{2}$

This article addresses the impact of privatization on universities in the United States, focusing, in particular, on the effects on the university mission and academic research in the life sciences. Both public and private nonprofit universities have been affected by public policies of privatization, leading to

* Associate Professor of Labor Law, School of Industrial and Labor Relations, Cornell University; associated faculty, Cornell Law School. B.A. 1976, University of Florida; J.D. 1979, University of Florida. I would like to thank my colleague, Alfred C. Aman, Jr. for inviting me to participate in the Indiana Journal of Global Legal Studies Symposium on Globalization and Education. I would also like to thank the participants at that conference for their insightful comments on my presentation, which formed the basis for this article.

1. See, e.g., Guy Brucculeri, A Need to Refocus the Mandate of the International Monetary Fund and the World Bank, 17 W.R.L.S.I. 53, 70-73 (2004). See generally Eugenia McGill, Poverty and Social Analysis of Trade Agreements: A More Coherent Approach?, 27 B.C. INT'L \& CoMp. L. Rev. 371, 371-84 (2004).

2. See infra notes $165-94$ and accompanying text. 
increased commercialization of academic research and growing universityindustry ties. These changes in practices have been accompanied by a significant weakening of the traditional definition of the university mission of serving the public interest through university teaching and research independent from conflicting interests of either government or business. Tied closely to university independence has been the core value of faculty academic freedom, protecting faculty autonomy over their work and enabling them to ensure the integrity of teaching and research that is independent from conflicting interests. ${ }^{3}$

The university's mission and the rights of faculty also describe the social role of the university and its faculty. Where the university has a public mission, its social role is defined in terms of promoting the public interest. ${ }^{4}$ Its policies and practices should, therefore, be aimed toward carrying out its public mission. As the university's mission becomes privatized, however, its social role is redefined as well, shifting from the public interest to serving private economic interests. Given the dominant influence of the United States in promoting private market economies globally, the social implications of privatizing the university's mission will extend beyond the national borders as well.

This article begins with a discussion of the traditional definition of the university's public mission and faculty academic freedom, which have formed the core elements of faculty identity in the university. In part II, the discussion moves to legal developments promoting privatization that have had a major impact on these traditional definitions of university mission and faculty rights. The relevant legal developments have taken place at both the national and international levels. At the national level, these changes have been aimed specifically at the university, with the federal Bayh-Dole Act of $1980,{ }^{5}$ which authorizes and encourages federal fund recipients-including universities - to patent and license federally funded research. As a consequence of the Bayh-Dole Act, universities have expanded their private market activities, leading to a major growth in university-owned patents and licensing of patents to industry. The article explores the impact of increased market activities at three levels: at the local level, on university culture and

3. See infra notes 7-32 and accompanying text.

4. See American Association of University Professors, 1940 Statement of Principles on Academic Freedom and TenURe, available at http:/www.aaup.org/statements/Redbook/ 1940stat.htm\#back la ("Institutions of higher education are conducted for the common good and not to further the interest of either the individual teacher or the institution as a whole. The common good depends upon the free search for truth and its free exposition.").

5. See Bayh-Dole Act of 1980, 35 U.S.C. $\$ \S 200-12$ (2001). 
research; at the national level, on the university's public mission; and at the international level, on the social implications of the university's involvement with expanding intellectual property rights. The article examines the international consequences of this commercialization by examining the World Trade Organization (WTO) multilateral trade agreement known as TRIPS-the Agreement on Trade-Related Aspects of Intellectual Property Rights. ${ }^{6}$ The 1994 TRIPS agreement, which requires WTO signatories to enact national laws protecting intellectual property rights, was not created with universities in mind. But with the increase of university-industry exclusive licensing agreements, university intellectual property practices take on global implications, as TNCs rely on TRIPS to reap the global benefits of their monopoly over university-owned patents. Part III of the article further explores the national and international social implications of the privatization and commercialization of the university and the need for faculty to recognize their role in either promoting or opposing these changes. This discussion suggests some forms of individual and collective action that faculty can take to reverse the privatization practices in the university and to reassert the university's public mission.

\section{Faculty Identity: Defining the Content and Process of Academic Work}

University faculty form their identity in relation to both the content of their work and the process by which they carry out their work. In terms of content, faculty identify strongly with their academic discipline and typically define their work life in terms of three categories: teaching, research, and service. ${ }^{7}$ While the content of their work might appear to be of primary importance, the work process is at least as important to faculty identity. At the heart of the work process is the core value of academic freedom, which provides faculty with autonomy over their work. At the level of individual autonomy, academic freedom provides

6. See Agreement on Trade-Related Aspects of Intellectual Property Rights, Apr. 15, 1994, Marrakesh Agreement Establishing the World Trade Organization, Annex 1C, Legal Instruments-Results of the Uruguay Round vol. 31 , 33 I.L.M. 81 (1994).

7. See, e.g., Sheldon Krimsky, Science in the Private Interest: Has the Lure of Profits Corrupted Biomedical Research? 218 (2003); Cornell University Faculty Handbook 42 (2002), available at http://web.cornell.edu/UniversityFaculty/ ("The responsibilities of a faculty member include teaching, research, and other scholarly achievement, public service, advising students, and contributing to the department, the college, and the university."). 
each faculty member with control over teaching and research content and methods. ${ }^{8}$ Individual faculty academic freedom also provides faculty members with the right to express their views publicly about the university or about issues unrelated to the university, including political issues. ${ }^{9}$ Collective faculty academic freedom provides faculty with autonomy to engage in self-governance of teaching, research, and service. Through faculty service on departmental and university committees, and through governance processes such as faculty senates and unions, faculty exercise collective authority over issues such as curriculum, graduation requirements, student admissions, as well as in judging the merit of colleagues' work in hiring and promotions processes. ${ }^{10}$ Individual academic freedom and collective academic freedom are often in harmony, particularly where the collective autonomy of self-governance supports individual faculty members' ability to pursue their teaching and research interests. These two aspects of academic freedom may be in tension, though, as the collective judgment of the faculty may be at odds with the full exercise of individual academic freedom. The exercise of faculty self-governance can, itself, lead to violations of academic freedom in cases where tenured faculty abuse their power by denying tenure to a candidate on the basis of bias against the tenure candidate's politics or research perspectives."

The faculty work process includes the creation of the work as well as the sharing of the work with others through informal exchanges of research ideas and results, and formal sharing of work through publication in books and journals. This process of sharing work has multiple functions that intertwine the

8. See, e.g., J. Peter Byrne, Academic Freedom: A "Special Concern of the First Amendment", 99 Yale L.J. 251, 273-76 (1989); Risa L. Lieberwitz, The Corporatization of the University: Distance Learning at the Cost of Academic Freedom?, 12 B.U. PuB. INT. L.J. 73, 80-85 (2002); Walter P. Metzger, Profession and Constitution: Two Definitions of Academic Freedom in America, 66 TEx. L. Rev. 1265, 1276-81 (1988) (discussing the process of achieving university autonomy).

9. See Metzger, supra note 8, at 1275; see also Matthew W. Finkin, “A Higher Order of Liberty in the Workplace": Academic Freedom and Tenure in the Vortex of Employment Practices and Law, 53 Law \& Contemp. Probs. 357, 372 (1990).

10. Lieberwitz, supra note 8 , at 84-85.

11. See Chester Hartman, Uppity and Out, A Case Study in the Politics of Faculty Reappointments (and the Limitations of Grievance Procedures), in How Harvard Rules, Reason in the Service of Empire 287 (John Trumpbour ed., 1989) [hereinafter How Harvard Rules]; Jamin B. Raskin, Laying Down the Law, The Empire Strikes Back, in How Harvard Rules, supra, at 341; Ellen Schrecker, Academic Freedom: The Historical View, in Regulating the Intellectuals: Perspectives on Academic Freedoms in the 1980s, 25, 25-27 (Craig Kaplan \& Ellen Schrecker eds., 1983) [hereinafter Regulating the Intellectuals]. 
content and the process of faculty work. First, broad dissemination of work expands access to knowledge in the public domain. ${ }^{12}$ Openness of research methods and results enables others to test the validity of the research. ${ }^{13}$ Sharing of research also enables further faculty research to build on the scholarship of others. ${ }^{14}$ Additionally, collective self-governance in judging the merit of work in promotion reviews depends on respect for a system of peer review. ${ }^{15}$

From both a legal and sociological perspective, the most interesting aspect of academic freedom is its strength as a deeply held professional norm rather than as a legal right. ${ }^{16}$ The United States Supreme Court did not recognize a First Amendment right of academic freedom until 1967 in Keyishian v. Board of Regents. ${ }^{17}$ The effectiveness of this constitutional right is restricted by the doctrine of state action, which limits application of the right to faculty in public sector universities. ${ }^{18}$ Substantive interpretations of the First Amendment and academic freedom have further reduced the strength of a constitutional right of academic freedom for faculty. First, the Supreme Court has diluted First Amendment rights for public sector employees by applying a balancing test that heavily favors governmental managerial interests over public employee free

12. Many authors have addressed the communal norms of academic science. See, e.g., Bernard Barber, Science and the Social Order (1953); Robert K. Merton, The Sociology of Science (1973); Rebecca S. Eisenberg, Proprietary Rights and the Norms of Science in Biotechnology Research, 97 Yale L. J. 177, 181-84 (1987); Arti Kaur Rai, Regulating Scientific Research: Intellectual Property Rights and the Norms of Science, 94 Nw. U. L. Rev. 77, 88-94 (1999-2000).

13. See Eisenberg, supra note 12, at 182; Rai, supra note 12, at 89-90.

14. See Eisenberg, supra note 12, at 183; Rai, supra note 12, at 90.

15. See Lieberwitz, supra note 8 , at 84-85.

16. See id. at $81,89-96$.

17. Keyishian v. Bd. of Regents, 385 U.S. 589 (1967) (striking down as vague and overbroad under the First Amendment New York's Feinberg Law, which conditioned employment in public education on taking loyalty oath and barred public employment of members of "subversive" organizations). Keyishian was preceded by Sweezy v. New Hampshire, 354 U.S. 234 (1957), in which the concept of academic freedom was developed without explicitly adopting academic freedom as a constitutional right. The Court held that the State violated due process by finding Sweezy, a Marxist economist, in contempt for refusing to answer questions concerning his university lectures and other questions concerning political association during a State investigation of public employment of "subversive persons."

18. Metzger, supra note 8 , at 1291 . Private university faculty could raisc constitutional claims concerning actions taken against individual faculty or the university by legislatures or other government officials. Id. at 1291-92; see also David M. Rabban, A Functional Analysis of "Individual" and "Institutional" Academic Freedom Under the First Amendment, 53 Law \& Contemp. Probs. 227, 300 (1990). 
speech interests. ${ }^{19}$ This test, which is a substitute for traditional First Amendment strict scrutiny, has been used by lower federal courts in public sector faculty academic freedom cases. ${ }^{20}$ Additionally, the lower courts have accorded judicial deference to a university's institutional right of academic freedom to manage the university, which may override faculty claims that the university administration has violated faculty academic freedom. ${ }^{21}$ Thus, the university's institutional academic freedom against governmental interference has been extended to strengthen the university's managerial control over faculty. As a result of these jurisdictional and substantive factors, the potential of academic freedom as a legal right of faculty has been significantly weakened.

From where, then, does faculty academic freedom derive its power as a professional norm? The answer lies in the history of faculty demands for the auton-

19. The Supreme Court initially created its balancing test in 1968 in Pickering v. Board of Educ., 391 U.S. 563 (1968), and further developed it in Connick v. Myers, 461 U.S. 138 (1983); Rankin $v$. McPherson, 483 U.S. 378 (1987); and Waters v. Churchill, 511 U.S. 661 (1994). The Court balances the "interests of the [public employee], as a citizen, in commenting upon matters of public concern and the interest of the State, as an employer, in promoting the efficiency of the public services it performs through its employees." Pickering, 391 U.S. at 568. See Lieberwitz, supra note 8, at 90-92 (discussing the balancing test).

20. There are cases that deny First Amendment protection for speech that would fit within the scope of professional academic freedom. See, e.g., Landrum v. E. Ky. Univ., 578 F. Supp. 241 (E.D. Ky. 1984) (academic curriculum); Ballard v. Blount, 581 F. Supp. 160 (N.D.Ga. 1983) (administrator's performance and denial of tenure), aff d, 734 F.2d 1480 (11 th Cir. 1984), cert. denied, 469 U.S. 1086 (1984). There is a discussion of Landrum and Ballard in Matthew W. Finkin, Intramural Speech, Academic Freedom, and the First Amendment, 66 Tex. L. Rev. 1323, 1326 (1988). See also Scallet v. Rosenblum, 911 F. Supp. 999 (W.D. Va. 1996) (holding that an administrator's interest in educational mandate outweighed plaintiff's right to decide academic curriculum); Bishop v. Aronov, 926 F.2d 1066 (11th Cir. 1991) (deciding that a University's interest in teaching mission outweighed professor's right to editorialize religious beliefs in the classroom). Several other articles have also discussed Scallet and Bishop. See, e.g., Rachel E. Fugate, Choppy Waters are Forecast for Academic Free Speech, 26 Fla. St. U.L. Rev. 187, 205 (1998); Richard H. Hiers, Academic Freedom in Public Colleges and Universities: $O$ Say, Does that Star-Spangled First Amendment Banner Yet Wave?, 40 W AYNE L. Rev. 1, 61 (1993).

21. Alisa W. Chang, Note, Resuscitating the Constitutional "Theory" of Academic Freedom: A Search for a Standard Beyond Pickering and Connick. 53 Stan. L. Rev. 915, 930-37 (2001); Matthew W. Fink in, On "Institutional" Academic Freedom, 61 Tex. L. Rev. 817 (1983); Hiers, supra note 20, at 17-19; Metzger, supra note 8, at 1310-19. There are discussions of the difficulties of litigating constitutional academic freedom as an individual right, given the Supreme Court's description of academic freedom in cases such as Keyishian as a protection of educational institutions from governmental interference. See, e.g., Byrne, supra note 8, at 298; Chang, supra, at 922; see also, Rabban, supra note 18 , at $280-82$ (describing constitutional academic freedom as an "individual" and an "institutional" right). 
omy and independence that comprise the core values of academic freedom. Decades before the Supreme Court recognized a constitutional concept of academic freedom, faculty engaged in collective struggles for autonomy in their research and teaching. The founding of the American Association of University Professors (AAUP) in 1915 grew out of university dismissals of faculty in the social sciences, whose social critiques were at odds with the interests of industrialists who were also financial donors to the universities. ${ }^{22}$ The AAUP's demands for academic freedom were, therefore, grounded in the need for faculty autonomy and independence from all third party interests, which include the university administration, government, and private donors. ${ }^{23}$ The AAUP based its rationale for these demands on the essential nature of academic freedom to enable faculty to engage in research and teaching that fulfill the institutional role of universities in society. The AAUP 1915 Declaration of Principles ${ }^{24}$ and the AAUP 1940 Statement of Principles on Academic Freedom and Tenure ${ }^{25}$ describe the values underlying academic freedom, which remain the foundation for the current professional norm of academic freedom. ${ }^{26}$ These statements justify faculty academic freedom in relation to the social role of the university, which has a mission to contribute to the public good. ${ }^{27}$ Academic freedom enables faculty to serve the public interest by

22. See Richard Hofstadter \& Walter P. Metzger, The Development of Academic Freedom in the United States 419, 426-27, 439 (1955); Ellen W. Schrecker, No Ivory Tower: McCarthyism and the Universities 14-17 (1986).

23. Byrne, supra note 8, at 273-76; Metzger, supra note 8, at 1276-81 (1988).

24. AaUP 1915 Declaration of Principles, reprinted in Academic Freedom and Tenure: A Handbook of the American Association of University Professors 155, 166-68 (Louis Joughin ed., 1967) [hereinafter 1915 Declaration].

25. 1940 Statement of Principles on Academic Freedom and Tenure, reprinted in AaUP Policy Documents \& Reports 3 (B. Robert Kreiser ed., 9th ed. 2001) [hereinafter 1940 Statement].

26. The 1940 Statement of Principles, which has been widely accepted by academic organizations and institutions, has been described as "adher[ing] to, adapt[ing], and strengthen[ing]" the principles of the 1915 Declaration. 1915 Declaration, supra note 24, at 157. The 1915 Declaration has been called "the single most important document relating to American academic freedom." Byrne, supra note 8, at 276; and "the first comprehensive analysis of academic freedom in the United States, [which] remains the foundation for the nonlegal understanding of academic freedom within the academic world." Rabban, supra note 18, at 232. For a discussion of the effectiveness of the AAUP's 1940 Statement, which was based on the 1915 Declaration, in shaping the norms and practices of the academic profession, see Matthew W. Finkin, Regulation by Agreement:The Case of Private Higher Education, 65 Iowa L. Rev. 1119, 1150-55 (1980).

27. 1915 Declaration, supra note 24 , at 160 (describing the university's identity as a "public trust"); 1940 STATEMENT, supra note 25, at 3 (describing the university's mission of contributing to the "common good"). 
engaging in teaching and research that meet the standards of their profession, without concern for pleasing university administrators, government officials, or private business donors. ${ }^{28}$ Thus, faculty autonomy and independence are necessary elements for ensuring work of high quality and integrity that deserves the public trust. The protection of lifetime tenure provides faculty with job security needed to reinforce the right of academic freedom, insulating faculty from pressures to conform their teaching and research to serve third party interests. ${ }^{29}$

This understanding of the underlying justifications for academic freedom is the antithesis of the stereotype of the university as an "ivory tower." Faculty autonomy and independence are not justified as a means to alienate faculty from society, but rather to enable faculty to fulfill a social role of contributing to the public good through work that is disinterested in the sense that faculty do not seek to serve third party interests. This independence is essential to uphold public trust in the integrity of the research and to avoid any actual influence over the research results. ${ }^{30}$ The "disinterested" researcher can certainly reach strong conclusions or provide pointed social critiques that are consistent with the positions held by third parties. These conclusions and critiques are more deserving of public trust owing to faculty academic freedom from the obligation to serve third party interests in their research, whether those third parties are the university administration, governmental agencies, or corporate donors.

Even with recent privatization trends in the university, faculty continue to exercise a significant degree of autonomy and independence in their academic research. Academic freedom has given individual faculty control over their research agendas, enabling them to pursue research regardless of the benefits or disadvantages to private or governmental interests. Peer review of publications and the sharing of research in the public domain remain the standard practices for promoting excellence of research, for contributing to the progress of the academic discipline, and for building individual faculty reputations in their fields. ${ }^{31}$

28. 1915 Declaration, supra note 24 , at 162.

29. See generally 1940 Statement, supra note 25, at 4 (discussing the privileges of tenureship).

30. See Rai, supra note 12, at 91 n.67 (describing the value of "disinterestedness" in academic science, as equating the researcher's interest with the public interest of expanding knowledge, rather than serving a narrow personal interest.); Eisenberg, supra note 12, at 183-84.

31. See American Association of University Professors, Good Practice in Tenure Evaluation: Advice for Tenured Faculty, Department Chairs, and Academic Administrators 1819 (2000), available at www.aaup.org/Com-a/resources.htm\#articles (last visited Jan. 24, 2005); Lisa Guernsey \& Vincent Kiernan, Journals See the Internet as a Tool in the Peer-Review System, Chron. Higher Educ., Apr. 2, 1999, at A29. 
In the sciences, which are the primary focus of this article, strongly held values of "communalism" have long been the foundation of academic culture, reflecting the belief that the quality of academic research content and process is based not only on individual accomplishments, but also on openly sharing information, ideas, and research results in the public domain. ${ }^{32}$

\section{Social and Political Challenges to Traditional Academic Values}

\section{A. Privatization Policies in Law and Practice}

The preceding description of academic freedom presents an ideal description of faculty autonomy and independence. While providing important protections and power to faculty, the reality of academic freedom exists within the context of social, economic, and political conditions that lead to policies and practices that fall short of the ideal of academic freedom..$^{33}$ In part, academic freedom is compromised by the very structure of universities, which rely on funding from both governmental appropriations and from private contributions. ${ }^{34}$ Although institutional and individual academic freedom should create a wall of separation of academic work from funding sources, the fear of losing funding can place powerful pressures on the university and faculty to please the funders. ${ }^{35}$ The origins of the AAUP demonstrate the potential power of private corporate donors to pressure universities to serve their economic interests, as the scale of corporate donations grew from thousands to millions of dollars during the industrialization period of the early

32. Rai, supra note 12, at 90 n.67 (describing the value of "disinterestedness" in academic science, as equating the researcher's interest with the public interest of expanding knowledge, rather than serving a narrow personal interest). See also Risa L. Lieberwitz, University Science Research Funding: Privatizing Policy and Practice, in Science and the University (Ronald G. Ehrenberg \& Paula E. Stephan eds., University of Wisconsin Press, forthcoming). See generally Bar Ber, supra note 12 (describing the general work in the sociology of science); MerTon, supra note 12; Eisenberg, supra note 12, at 181-84; Rai, supra note 12, at 88-94.

33. See, e.g., Milton Fisk, Academic Freedom in Class Society to The Concept of Academic FreeDom 5 (Edmund L. Pincoffs ed., 1972); Craig Kaplan, Introduction to Regulating the IntellectuALs, supra note 11, at 1, 3; Lawrence S. Lifschultz, Could Karl Marx Teach Economics in the United States?, in How Harvard Rules, supra note 11, at 279; Bertell Ollman, Academic Freedom in America Today: A Marxist View, in Regulating the Intellectuals, supra note 11, at 45, 47; Frances Fox Piven, Academic Freedom and Political Dissent, in Regulating the Intellectuals, supra note 11, at 17, 18-19.

34. See Rebecca S. Eisenberg, Academic Freedom and Academic Values in Sponsored Research, 66 Tex. L. Rev. 1363, 1363-64, 1371-72 (1988).

35. Id. at 1372-76. 
twentieth century. ${ }^{36}$ In debates over its founding principles, a syndicalist faction of the AAUP advocated that all universities should be supported solely by public funds, with broad faculty governance that included faculty control over appointments of administrators and university officers. ${ }^{37}$ This proposal was defeated, however, with the AAUP opting for demands for academic freedom within the existing system that provided significant decision-making power to university administrators, who continued to seek large private corporate contributions. ${ }^{38}$

Public funding of universities has the benefit of placing appropriations decisions in an open, democratic process, in which the public interest is an explicit goal. Even in this public context, of course, threats to academic freedom remain. Deeply internalized and strongly institutionalized norms of academic freedom are essential to enable universities and faculty to resist pressures from the political process, including the influence of private corporations in political decisions, the government's efforts to involve universities in secret military research, and political attacks during periods such as the McCarthy era, when many universities succumbed to pressures to purge the Left from the faculty. ${ }^{39}$ While recognizing these realities, public funding has the advantage of providing a democratic forum for debates and decision-making regarding the best way to serve the public interest. This focus on the public interest is consistent with the public mission of the university and the value of academic freedom.

Following World War II, federal funding became the primary support for academic research, consistently providing universities with at least 60 to 70 percent of research support since $1960 .{ }^{40}$ Public funding has maintained its importance for

36. See Hofstadter \& Metzger, supra note 22, at 413.

37. Id. at 473; see also Schrecker, supra note 22, at 25-27; Byrne, supra note 8, at 278-79; Metzger, supra note 8 , at $1276-78$.

38. Within this division of power, faculty self-governance over academic matters is limited by the final authority of the administration. See, e.g., Byrne, supra note 8, at 278-79; Metzger, supra note 8, at 1276-78; Schrecker, supra note 11, at 25-27. See generally Hofstadter \& MetzGer, supra note 22 , at 473 (discussing a proposed plan for academic freedom).

39. See Howard Zinn, The Politics of History in the Era of the Cold War: Repression and Resistance, in The Cold War and the University: Toward An Intellectual History of the Postwar YEARS 35, 52-71 (1997).

40. E.g., Martin Kenney, Biotechnology: The University-Industrial Complex 35-36 (1986); Eyal Press \& Jennifer Washburn, The Kept University, Atr. Monthly, Mar. 2000, at 40. See also Sheila Slaughter \& Gary Rhoades, The Emergence of a Competitiveness Research and Development Policy Coalition and the Commercialization of Academic Science and Technology, 21 Scr. Tech. \& Hum. VALUEs 303, 327 (1996) (discussing the decline in funding from 1973, when 69\% of university R\&D was federally funded, to 1993 , when $56 \%$ of university R\&D was supported by federal funds). 
university life sciences research, estimated at 70 to 80 percent of total funding. ${ }^{41}$ Although the postwar concentration of federal funding was at least partly attributable to Congress' political motivation of competing with the Soviet Union, ${ }^{42}$ the system of federal funding grants has led to institutional structures that correspond with values of academic freedom. Federal grants are awarded by federal agencies, such as the National Institutes of Health (NIH) or the National Science Foundation (NSF), on the basis of peer review processes. ${ }^{43}$ Although a federal agency can shape research agendas through its descriptions of research interests and grants awarded, the peer review process and the public interest mission are important for limiting arbitrary use of agency power and for excluding personal financial interests from the process. ${ }^{44}$ Prior to 1980 , publicly funded research results generally became part of the public domain, freely available to academic researchers or other parties to test its accuracy or to use in further research. ${ }^{45}$ Federal law favored granting government title to inventions developed with federal funds ${ }^{46}$-a policy that encouraged placing these inventions in the public domain. ${ }^{47}$ The government agency could choose to dedicate an invention to the public domain by publishing the results without obtaining a patent or by providing nonexclusive licenses to private parties seeking to use a government-owned patent. ${ }^{48}$ Therefore, supporting a high percentage of academic research with public funds was consistent with the university's public mission and with academic freedom in providing grants in the

41. David Blumenthal, Biotech in Northeast Ohio Conference: Conflict of Interest in Biomedical Research, 12 Health Matrix 377, 380 (2002); Kenneth Sutherlin Dueker, Biobusiness on Campus: Commercialization of University-Developed Biomedical Technologies, 52 Foov \& Drug L.J. 453, 457 (1997).

42. See R. C. Lewontin, The Cold War and the Transformation of the Academy, in THE COLD WAR ANd the University 1, 20-28 (1997). See generally Kenney, supra note 40, at 13-15, 32-33.

43. See Jeffrey Brainard, NIH Callsfor Removal of Grant-Proposal Reviewers Who Have Conflicts of Interest, Chron. Higher Educ., Jan. 16, 2004, at 22; Paulette Walker Campbell, Plan to Revamp NIH PeerReview Process Draws Mixed Assessment, Chron. Higher Educ., Nov. 19, 1999, at A40; Jeffrey Brainard, Reassessing an NSF Program for Research Have-Nots, Chron. Higher Educ., Oct. 15, 1999, at A31.

44. See Krimsky, supra note 7, at 204-07 (describing federal agency conflict of interest policies).

45. See Rebecca S. Eisenberg, Public Research and Private Development: Patents and Technology Transfer in Government-Sponsored Research, 82 VA. L. REv. 1663, 1663 (1996); Rai, supra note 12, at 92-93.

46. See Eisenberg, supra note 45, at 1671-91 (discussing the pre-1980 development of federal statutes, agency regulations, and executive orders affecting title to federally funded research discoveries); see id. at 1677 ("Congress did not ... adopt a uniform policy vesting ownership of all federallysponsored research discoveries in the government, although over the years it did enact such a policy on a more limited basis in a number of statutes applicable to particular programs or agencies.").

47. Id. at 1663 .

48. Eisenberg, supra note 45, at 1675-76; Rai, supra note 12, at 97 n.113. 
public interest, protecting faculty autonomy and independence, and preserving communal values through expansion of the public domain.

The major economic, social, and political shifts of the 1980s had corresponding effects on the institutional policies and practices of academic research. The Bayh-Dole Act of 1980, which was enacted in the early stages of privatization, authorized and encouraged federal fund recipients-including universities- to patent the results of their federally funded research. ${ }^{49}$ The Bayh-Dole Act shifts the presumption of ownership of federally funded inventions from title in the government to title in the recipient of the federal funds. Under the statutory presumption of Bayh-Dole, the federal agency can retain title to the invention only by demonstrating "exceptional circumstances" that support a determination that this will "better promote the policy and objectives" of the Act. ${ }^{50}$ This shift of presumptive title changes the public policy priority from using public funding to expand the public domain towards private control of federally funded research. Congress justified this change as a means of promoting the commercialization of the inventions developed through publicly funded research programs with particular emphasis on the collaboration between universities and businesses. ${ }^{51}$ The university could now profit on its patents on federally funded research results by licensing them to third parties, including exclusive licenses to for-profit corporations. ${ }^{52}$

The impact of the Bayh-Dole Act was strengthened by two additional phenomena. First, the field of molecular biology exploded in the mid-1970s with the

49. 35 U.S.C. $\$ 200$ (2000); see Eisenberg, supra note 34, at 1665. The Bayh-Dole Act originally allowed nonprofit organizations and small businesses to apply for patents on research results that had been funded in whole or in part with federal funds. The Bayh-Dole Act was soon amended to expand patenting rights to all businesses receiving federal research funds, regardless of the size of the business. The extension of the Act to large business was done first by a Presidential Memorandum in 1983 and then by Congress in a 1984 amendment to the Bayh-Dole Act. Id. at 1694-95, 1707 n. 180 .

50. 35 U.S.C. $\$ 202$ (2000); see Rai, supra note 12, at 147-48. Where the federal fund recipient chooses to apply for a patent, the federal funding agency retains a nonexclusive license to use the publicly funded invention. Eisenberg, supra note 12, at 196. The Bayh-Dole Act also gives federal agencies "march-in rights" to require the government contractor to issue licenses on a patent when needed to "achieve practical application" of the invention. 35 U.S.C. $\$ 203(a)$ (2000). Federal agencies rarely, if ever, exercise these march-in rights. Peter Mikhail, Hopkins v. CellPro: An Illustration that Patenting and Exclusive Licensing of Fundamental Science is Not Always in the Public Interest, 13 Harv. J. LAW \& TECH. 375, 382 (2000).

51. 35 U.S.C. $\$ 200$ (2000); see also Arti K. Rai \& Rebecca S. Eisenberg, Bayh-Dole Reform and the Progress of Biomedicine, 91 Amer. Scientist 52, 54 (Jan-Feb. 2003).

52. Eisenberg, supra note 45, at 1663-65. 
discovery of the recombinant DNA (rDNA) process, which launched major advances in genetic engineering research and biotechnology. ${ }^{53}$ This shift in molecular biology from "an analytic to a synthetic science" ${ }^{\text {" }}$ opened the commercial potential of the life sciences..$^{55}$ Additionally, the federal courts became more "pro-patent" in the field of life sciences following the United States Supreme Court's 1980 decision in Diamond v. Chakrabarty ${ }^{56}$ that life forms "made by man" can be patented. ${ }^{57}$ In 1982, Congress created the Federal Circuit Court to exercise exclusive jurisdiction over patent appeals from the federal district courts. ${ }^{58}$ The Federal Circuit has built on the Supreme Court's pro-patent doctrine in Chakrabarty to expand the potential for patents in the genetics field, including patents of gene fragments. ${ }^{59}$

53. Sheldon Krimsky, The Profit of Scientific Discovery and Its Normative Implications, 75 CHI.Kent L. Rev. 15, 16-17 (1999).

54. Id. at 17-18. Professor Krimsky describes this event:

In that monumental discovery, the biological sciences had made the transition from an analytic to a synthetic science.... The introduction of rDNA technology established the absolute fungibility of genes, opening up possibilities for synthesizing new organisms and establishing revolutionary methods for mass producing biological products. The commercial opportunities of this discovery were recognized immediately by scientists.

Id. (citation omitted).

55. Id. Professor Kenney describes this invention as "the single pivotal event in the transformation of the 'basic' science of molecular biology into an industry." KenNey, supra note 40, at 23. The potential commercial value of basic research has also been enhanced by the blurred distinction between basic and applied research in the biomedical field and the resulting shortened time period between basic research and its application. Id. at 106; see also Eisenberg, supra note 12, at 196, 178 n.l (defining "basic research" as " "pure' research directed solely toward expanding human knowledge, as opposed to 'applied' research directed toward solving practical problems[,]" and noting that "whatever validity this dichotomy may have in other contexts, it is difficult to maintain in the context of contemporary biotechnology research."); Rai, supra note 12, at 77 n.1.

56. Diamond v. Chakrabarty, 447 U.S. 303 (1980).

57. Id. at 309. The Court held that a genetically engineered bacterium that degraded crude oil was patentable subject matter. The Court agreed that "products of nature, whether living or not" are not patentable, but concluded that "human-made inventions," including living materials, may be patented, defining the scope of patenting to "include anything under the sun that is made by man." Id. at 313 (citation omitted).

58. See Kenneth J. Burchfiel, Biotechnology and the Federal Circuit 4-5 (Dale H. Hoscheit \& Lisa M. Hemmendinger eds., Supp. 2000) (1995); see also Rai, supra note 12, at 102.

59. Yvonne Cripps, The Art and Science of Genetic Modification: Re-Engineering Patent Law and Constitutional Orthodoxies, Ind. J. Global Legal Stud., Winter 2004, at 1, 4-10 (2004) (offering her "belief that the extraordinary nature of biotechnology has altered the ways in which the fundamental, traditional tenets of patent law are applied in that field[,]" lowering the standards of the "classic tenets requir[ing] an invention that is, among other things, novel, nonobvious, and useful.") (emphasis in original); Rai, supra note 12, at 100-09. 
Thus, the Bayh-Dole Act was planted in the fertile ground of pro-patent policy in the courts and revolutionary developments in university genetics research, leading to dramatic changes in university research policy and practice. Following Bayh-Dole, universities expanded their technology transfer offices to provide the infrastructure and personnel to "scour [university] labs" ${ }^{\prime 0}$ for commercially profitable discoveries. The patent rate by U.S. universities soared from 264 patents obtained in 1979, before the Bayh-Dole Act, to nearly ten times that number in 1997 , with 2,436 patents. ${ }^{61}$ In fiscal year 2000 , U.S. universities filed 8,534 patents, an increase of 12 percent over $1999 .{ }^{62}$ From 1980 to 1990, patent applications on NIH-funded inventions increased by almost 300 percent. ${ }^{63}$ Surveys of U.S. universities in 1991 and 2000 show that during that period new patent applications increased by 238 percent, licensing agreements increased by 161 percent, and royalties increased by more than 520 percent. ${ }^{64}$ About half of the university-industry licensing agreements provide exclusive licenses to forprofit corporations. ${ }^{65}$ U.S. universities regularly apply for patents, not only in the United States, but also in Europe, Canada, Australia, and Japan. ${ }^{66}$ U.S. universities also file for patents in "middle-income" developing countries, including South Africa, Brazil, and India ${ }^{67}$ In least developed countries, U.S. universities generally authorize their licensees to file for patents, although the university remains the patent owner. ${ }^{68}$

60. Derek Bok, Universities in the Marketplace: The Commercialization of Higher EduCATION 141 (2003) (concluding that such commercial activities promote the public interest).

61. Rai \& Eisenberg, supra note 51, at 53.

62. Goldie Blumenstyk, Income From University Licenses on Patents Exceeded \$1-Billion, Chron. Higher Educ., Mar. 22, 2002, at A31.

63. Krimsky, supra note 53, at 22.

64. Jerry G. Thursby \& Marie C. Thursby, University Licensing and the Bayh-Dole Act, Sclence, Aug. 22, 2003, at 1052.

65. Id. (reporting by the Association of University Technology Managers).

66. Access to Essential Medicines and University Research: Building Best Practices 4 (Ctr. for Interdisc. Res. on AIDS, Yale University, Fall 2003), available at http://cira.med.yale.edu/ (last visited Sept. 23, 2004) [hereinafter Access to Essential Medicines]; see also Keeping Science Open: The Effects of Intellectual Property Policy on the Conduct of Science, The Royal Soc'y, at v (Apr. 2003), available at www.royalsoc.ac.uk (discussing the similar phenomenon of profit creation and protection of intellectual property rights "as a primary policy objective for UK publicly funded research.") (last visited Sept. 23, 2004) [hereinafter Keeping Science Open].

67. Access to Essential Medicines, supra note 66, at 4-5.

68. Id. at 4 . 
Given the continued dominant role of federal funding to support academic research, the Bayh-Dole Act remains the most important instrument for encouraging universities to increase their market activities through patents and licenses of publicly funded research results. ${ }^{69}$ Additionally, implementation of the BayhDole Act indirectly facilitates other university-industry relationships. Although public funds remain the greatest source of research support, corporate funding has grown significantly, increasing by 93 percent between 1980 and $1984,{ }^{70}$ with industry financing of the life sciences increasing from 7 percent of all academic scientific research in 1993 to nearly 11.7 percent in $1994 .{ }^{71}$ In the 1980 s and 1990 s, large-scale corporate funding of academic research increased through new funding arrangements, often referred to as Strategic Corporate Alliances (SCAs), involving multi-million dollar, multi-year corporate support for a university department or program in exchange for exclusive licensing rights over patents resulting from the academic research. ${ }^{72}$ These include the 1982 Washington University-Monsanto agreement for $\$ 23.5$ million of corporate funds

69. See Peter S. Arno \& Michael H. Davis, Why Don't We Enforce Existing Price Controls? The Unrecognized and Unenforced Reasonable Pricing Requirements Imposed upon Patents Deriving in Whole or in Part from Federally Funded Research, 75 Tul. L. Rev. 631, 669 (2001) (discussing a Government Accounting Office report finding that "[d]uring fiscal years 1989 and 1990, technologies developed with acknowledged NIH or NSF funding accounted for approximately $73 \%$ of all license income" in the 35 universities with the largest grants from these federal agencies) (citations omitted).

70. Eisenberg, supra note 12, at 178 n.2.

71. David Blumenthal et al., Relationships Between Academic Institutions and Industry in the Life Sciences-An Industry Survey, 334 New Enc. J. Med. 368, 369-71 (1996). A study of life sciences companies concludes that "life-science firms were significantly more likely to support academic research in 1994 than in $1984 \ldots$..." Id. at 371 (finding an increase from $46 \%$ to $57 \%$ of such firms). Another source reports that industry support of university research grew from " $\$ 1.45$ billion in 1994 to $\$ 2.16$ billion in 1999 , an annual increase of nearly 10 percent." Charles F. Larson, The Boom in Industry Research, 16 Issues IN SCI. \& TECH. 27, 27 (Summer 2000). Corporations' financial support of total academic research has been reported to have increased "from 2.3 percent in the early 1970 s to almost 8 percent by the year 2000." Вок, supra note 60, at 12 .

72. An early large-scale funding agreement was reached in 1974, between Harvard and Monsanto Corporation for a 12-year, $\$ 23$ million grant to Harvard Medical School in exchange for Monsanto's right to a worldwide exclusive license for inventions resulting from this research funding. KENNEY, supra note 40, at 58. After entering into this agreement, Harvard eliminated its policy, in existence since 1934, that had required approval from the president and fellows before obtaining university "patents primarily concerned with therapeutics or public health" and further requiring that such patents be taken only "for dedication to the public." Eisenberg, supra note 12, at 181 n.9 (quoting David Dickson, The New Politics of Science 89 (1984)). 
over five years in exchange for exclusive licensing rights to patents resulting from biomedical research, ${ }^{73}$ the 1994 MIT-Amgen agreement for $\$ 30$ million of corporate funding to the Department of Biology and the Department of Brain and Cognitive Sciences over a ten year period in exchange for resulting patents to be owned jointly by MIT and Amgen, ${ }^{74}$ the 1997 MIT-Merck agreement for $\$ 15$ million in corporate funds over five years in exchange for licensing rights to resulting patents, ${ }^{75}$ and the 1998 University of California at Berkeley-Novartis agreement for corporate funding of $\$ 25$ million over five years in exchange for exclusive licensing rights to about a third of the Plant and Microbial Biology department's discoveries. ${ }^{76}$

The trends toward private ownership of academic research have been embraced by individual faculty members who will share in the profits resulting from university-owned patents of their publicly funded research discoveries. ${ }^{77}$ Additionally, faculty relationships with industry have increased through expanded corporate research contracts and faculty consulting arrangements with industry. ${ }^{78}$ Faculty often enter into consulting arrangements with businesses while continuing their university teaching and research, with an estimate that about half of life sciences faculty members act as consultants for industry. ${ }^{79}$ Since the mid-1980s, 21 to 28 percent of life sciences faculty members have consistently received research support from industry. ${ }^{80}$ During that time period, about 7 to 8 percent of faculty members reported that they held equity in a company related

73. KENNEY, supra note 40, at 67-69; Krimsky, supra note 53, at 28-29. After being renewed three times, Monsanto's financing of the university came to about $\$ 100$ million. $I d$. at 28 .

74. Andrew Lawler, Last of the Big Time Spenders?, 299 SCIENCE 330 (2003); MIT's Alliances with Industry, MIT News, available at http://web.mit.edu/newsoffice/nr/2000/alliance.html (last visited Oct. 21, 2004).

75. William H. Honan, Corporations Still Give, But Also Get, N.Y. Times, July 15, 1998, at B9.

76. Novartis is a Swiss pharmaceutical corporation that also produced genetically engineered crops. Press \& Washburn, supra note 40, at 39; Vicky Elliott, Who Calls the Tune?, UNESCO Courier, Nov. 1, 2001, at 21. See also Goldie Blumenstyk, $A$ Vilified Corporate Partnership Produces Little Change (Except Better Facilities), Chron. Higher Educ., June 22, 2001, at 24.

77. The Bayh-Dole Act requires the university to share with a faculty inventor the profits from royalties related to a university-owned patent on an invention created wholly or partially with public funds. 35 U.S.C. $\$ 202$ (c)(7)(B) (2004).

78. See BoK, supra note 60 , at $62,151$.

79. See Blumenthal, supra note 41 , at 379 . See generally Krimsky, supra note 53.

80. See Blumenthal, supra note 41, at 378; see also Justin E. Bekelman et al., Scope and Impact of Financial Conflicts of Interest in Biomedical Research, 289 J. AM. MED. Ass' N 454, 456 (2003) (discussing studies showing extensive financial relationships between faculty and industry). 
to their research. ${ }^{81}$ During the 1980 s and 1990s, faculty participated in founding twenty-four Fortune 500 companies and over 600 non-Fortune 500 companies in the life sciences. ${ }^{82}$ A 1992 study found that about one-third of lead authors of 789 articles in leading scientific journals had financial interests in their research, including patents, equity ownerships, or a position on the advisory board or board of directors. ${ }^{83}$

\section{B. Impact of Privatization on the University: Local, National, and Global Implications}

Advocates of privatization and commercialization of academic research argue that the public, universities, and faculty all benefit from the increased marketing of academic research. ${ }^{84}$ From this perspective, commercialization of academic research is consistent with the university's public mission by promoting development of academic research that otherwise would be ignored. Exclusive licensing of university-owned patents on publicly funded academic research creates industry incentives to invest further capital needed to develop the patented results into marketable commercial products. Without this guarantee of exclusive control, for-profit corporations would not risk the capital needed to develop academic research that belongs to the public domain..$^{85}$ Advocates of commercialization also

81. Blumenthal, supra note 41, at 379.

82. Id. at 385 .

83. Bekelman, supra note 80, at 456 (discussing Sheldon Krimsky et al., Scientific Journals and Their Authors' Financial Interests: A Pilot Study, 67 Psycнотнеr. Psycноsом. 194 (1998)); see also Sheldon Krimsky et al., Financial Interests of Authors in Scientific Journals: A Pilot Study of 14 Publications, 2 Sci. \& ENg. Ethics 395, 395 (1996).

84. See, e.g., BoK, supra note 60, at 15-16, 28, 141; Lita Nelsen, The Role of University Technology Transfer Operations in Assuring Access to Medicines and Vaccines in Developing Countries, 3 Yale J. Health Pol'y L. \& Ethics 301, 301-02 (2003).

85. See Nelsen, supra note 84 , at 302. Supporters of the Bayh-Dole Act assert that privatizing federal research results will encourage utilization of federally funded inventions, citing evidence of the low licensing rate of government-owned patents prior to 1980 and the increase in university-owned patents and corporate licenses after 1980. See BoK, supra note 60, at 141; Eisenberg, supra note 45, at 1663-64, 1676-77, 1702; Eisenberg, supra note 12, at 181-82. As Professor Rebecca Eisenberg has argued, however, the statistical evidence concerning pre-1980 licensing understates the actual use of federally funded inventions, given the common practice of unlicensed use of government-owned patents and the availability of unpatented federally funded inventions and the pre-Bayh-Dole practice of the Department of Defense $(\mathrm{DoD})$ to permit private contractors to retain title to patents on DoD-sponsored research. Eisenberg, supra note 45, at 1702-04. In agencies such as Health, Education, and Welfare (HEW), which commonly retained title to federally funded inventions, the licensing rate was higher. Id. at 1703 . 
support the practice of exchanging private corporate research funds for exclusive licenses to university patents, arguing that a for-profit corporation will not invest in large-scale funding of academic research without guarantees of exclusive access to resulting patents. ${ }^{86}$ Advocates of such university-industry relationships also deny that there is a qualitative difference between the influences on academic research resulting from government agency funding as compared with private industry funding. ${ }^{87}$ In either case, they argue, research agendas will be shaped by the interests of the funding source and in both instances faculty will continue to exercise the same degree of academic freedom in choosing and implementing their research projects. ${ }^{88}$ Any concerns about additional coercion from private corporate interests can be addressed by negotiating agreements with corporate funders that protect faculty from excessive corporate oversight. ${ }^{89}$ The argument in favor of SCAs is bolstered by the university's need for millions of dollars to sustain modern scientific laboratories. ${ }^{90}$ Furthermore, advocates of commercialization view academic freedom as including faculty rights to profit from patented research, whether through university negotiated licenses or through spin off corporations founded by faculty. ${ }^{91}$

These arguments in support of privatization and commercialization of academic research equate the public interest with the private interests of for-profit corporations. ${ }^{92}$ From this viewpoint, corporate market position and profitability are the primary determinants of whether academic research reaches the public. Defining the public interest as synonymous with the corporate interest ignores

86. See Heather Hamme Ramirez, Defending The Privatization of Research Tools: An Examination of The "Tragedy of The Anticommons" In Biotechnology Research and Development, 53 Емову L.J. 359, 365-66, 373-74 (2004); Thursby \& Thursby, supra note 64.

87. See BoK, supra note 60 , at $61-62$; Blumenstyk, supra note 76.

88. Blumenstyk, supra note 76; Elliott, supra note 76.

89. See Boк, supra note 60, at 143-44; Tom Abate, Report Emphasizes Biotech's Need for Academic-Corporate Study; Authors Discuss How to Continue Research, Avoid Ethical Lapses, S.F. Chron., June 11, 2001, at D1.

90. See Blumenstyk, supra note 76.

91. See BoK, supra note 60, at 147-48; see also Rebecca S. Eisenberg, Academic Freedom and Academic Values in Sponsored Research, 66 TEx. L. Rev. 1363, 1380, 1384 (1988) (posing the question of how universities can both respect individual faculty academic freedom while also responding to the problem of private research sponsors seeking control over academic research where the faculty find such control acceptable).

92. See Risa L. Lieberwitz, The Marketing of Higher Education: The Price of the University's Soul, 89 Cornell L. Rev. 763, 782 (2004) (reviewing Derek Bok, Universities in the Marketplace: The Commercialization of Higher Education (2003)); Lieberwitz, supra note 32. 
both the conflict between the public interest and private corporate interests and the resulting damage to the public interest from privatization and commercialization of academic research. These negative consequences can be analyzed at three levels, beginning with the "local" context of the university, moving to the national level of consequences to the public in the United States, and finally, evaluating the social implications at a global level under multilateral trade agreements.

\section{Consequences at the "Local" Level of the University}

The conflict between public and private interests resulting from privatization and commercialization of academia is more than theoretical. In significant respects, private economic interests have won in this conflict, resulting in critical changes in university practices and the academic research culture. The public domain has been restricted through licensing of university-owned patents, approximately half of which are for exclusive corporate licenses. ${ }^{93}$ The nature of university research, which often makes discoveries of "upstream" research, amplifies the restrictive effects of patenting academic research discoveries. Upstream research refers to the results at early stages of research, such as isolation of gene sequences, which may be used as research tools in further research in multiple and diverse areas. ${ }^{94}$ Patents on upstream research have been criticized as impeding further research, owing to their overly broad scope, limits on their use under exclusive licenses, and the burdens and costs of non-exclusive licenses. ${ }^{95}$ One example is research concerning mutations of the HFE gene, which

93. See Thursby \& Thursby, supra note 64 and accompanying text.

94. See Michael A. Heller \& Rebecca S. Eisenberg, Can Patents Deter Innovation? The Anticommons in Biomedical Research, 280 Science 698, 699-700 (1998); Rai \& Eisenberg, supra note 51, at $55-56$.

95. See Cripps, supra note 59, at 4-12; Heller \& Eisenberg, supra note 94, at 699-700; Rai, supra note 12, at 107-08; Rai \& Eisenberg, supra note 51, at 54-56; KeePing SCIEnCE Open, supra note 66, at 9-13. See also Naomi Freundlich, Will Increasingly Aggressive Licensing Terms on Research Tool Patents Hurt Basic Research?, Signals Mag., June 4, 1998, at http:/www.signalsmag.com/signalsmag. nsf/61 dbel7a63981409882565ae00822f19/b931de6bb4a15ae78825661 8005b6335? OpenDocument (last accessed Oct. 4, 2004); Naomi Freundlich, Cre-lox Controversy Divides Institutions, Prompts NIH Panel, Signals Mag., June 12, 1998, at http:/www.signalsmag.com/signalsmag.nsf/ 657b06742b5748e888256570005cba01/a91504e7700ed9b0882566210046c958? OpenDocument (last accessed Oct. 4, 2004) (discussing the impediments to research caused by "reach-through" agreements, in which the owner of a patented upstream research tool seeks to share in the profits of subsequent downstream patents through licensing agreements that provide for royalties on furure sales of downstream products or for exclusive or nonexclusive licenses to use downstream discoveries). 
have been identified as central to the serious illness, hemochromatosis. Enforcement of privately owned patents on the HFE gene and tests for the gene has impeded research and diagnostic tests for the HFE gene mutations. ${ }^{96}$ Similar impediments are created by Myriad Genetics' broad patents on two breast cancer genes, BRCA1 and BRCA2, which cover mutations on the genes, the use of these mutations in medical diagnosis and screening for breast cancer, and the development of therapeutic treatment of cancers with mutations in either gene. ${ }^{97}$

The courts and the U.S. Patent Office have been criticized for loosening the criteria for patentability, particularly with regard to the nonobviousness and utility requirements, which ensure that an invention adds to scientific knowledge in a significant way and will be of immediate practical use. ${ }^{98}$ Lowered standards for judging these criteria, however, have resulted in patents issued on upstream research, including genes and gene sequences, which often falls in the realm of discoveries that will contribute to further research, rather than inventions with identifiable utility. ${ }^{99}$ Universities have, in some cases, aggressively protected their patent rights, including broad patents on upstream research discoveries. For example, Harvard, MIT, and the Whitehead Institute for Biomedical Research, together with their exclusive licensee, Ariad Pharmaceuticals, sued Eli Lilly \& Co. for infringement of a patent on a basic genetic research discovery (the cell-signaling

96. See Cripps, supra note 59, at 7. An example in the area of agriculture is the patenting of genes and patents on methods for isolating and cloning DNA, which have been identified as creating difficult obstacles that have delayed the development of beta-carotene-enriched "golden rice." See Roger N. Beachy, IP Policies and Serving the Public, 299 Science 473 (Jan. 24, 2003).

97. Bryn Williams-Jones, History of a Gene Patent: The Development and Application of BRCA Testing, 10 Health L.J. 123, 132-33 (2002). The discoveries of these breast cancer genes were based, in part, on academic research funded by the NIH. Id. Myriad charges health care providers approximately $\$ 2,700$ to administer the screening test to detect the presence of the two genes. Cripps, supra note 59 , at $6(\$ 2,680$ charge for the screening test); Krimsky, supra note 53 , at 37 $(\$ 2,400$ charge for the screening test). As Professor Cripps explains, this expense is prohibitive for individuals whose insurance does not cover the test and many hospitals and health care providers will not pay this high fee. Cripps, supra note 59 , at 6 . Without the licensing fees, the cost for the genetic test for breast cancer would be about $\$ 50$. Charles Leroux, Biotech's Traffic Cop: Chicago Attorney Lori Andrews Stands Where Science and the Law Intersect, CHI. Trib., Oct. 7, 2001, at C12.

98. See Cripps, supra note 59, at 4-5; Rai, supra note 12, at 107-08.

99. See Cripps, supra note 59, at 4-8. See also Keeping Science Open, supra note 66, at 9-13. 
pathway for nuclear factor kappa B), claiming the right to royalties on sales of products developed with the use of the patented research tool. ${ }^{100}$

The change in the relationship between universities and private financial supporters has been described as "a shift from corporate contribution to corporate investment in academia." ${ }^{101}$ Large-scale industry-university funding agreements commonly include provisions that break down the wall of separation between thirdparty financial supporters and academic research, limiting faculty independence and autonomy. SCAs condition multi-million dollar corporate funding upon significant corporate involvement in decisions over research grants, the presence of corporate representatives on campus, and corporate pre-publication review of research results. Specifically, in addition to exclusive licensing rights, SCAs have provided the funding corporation's representatives with seats on the university committees that review and select faculty research grant proposals, ${ }^{102}$ special access to faculty researchers and graduate students, ${ }^{103}$ and the right to delay publication for three to six months to review research results and for filing patent applications. ${ }^{104}$

Privatization and commercialization have also resulted in changes in the academic research process. Faculty report increased secrecy by their colleagues over

100. Rai \& Eisenberg, supra note 51, at 57 . This research discovery resulted from federally funded research by university scientists at Harvard, MIT, and the Whitehead Institute for Biomedical Research. Despite the importance of this basic research tool for further research on a wide range of diseases, the universities obtained "a broad patent claiming all drugs that work by inhibiting NF$\mathrm{Kb}$ cell signaling" and granted an exclusive license on the patent to Ariad Pharmaceuticals.

101. Charles C. Caldart, Industry Investment in University Research, $8 \mathrm{SCI}$. TeCH. \& Hum. VAlues, Spring 1983, at 24, 25.

102. See id. For example, the UC Berkeley-Syngenta (formerly Novartis) agreement gave Syngenta exclusive licensing rights to about a third of the department's discoveries and held two of five seats on the department's research committee that made decisions on distribution of the funds. Id.; Press \& Washburn, supra note 40, at 39-40. Syngenta was given the right to review all proposed publications and presentations by participating faculty and their graduate students, including publicly funded research. Blumenstyk, supra note 76 , at 24 . The agreement also authorized Syngenta to ask for a ninety-day publication delay to provide time for patent applications. Id. Novartis has large-scale funding agreements with other universities, including $\$ 24$ million paid over a six-year period to University of Maryland's Psychiatric Research Center in exchange for half the seats on the eight-member panel that distributes the funds, exclusive commercial access to its bank of brain tissue, and exclusive licensing rights to its patents. Douglas M. Birch \& Gary Cohn, Standing Up to Industry: As Corporations Increasingly Hold Their Purse Strings, Many Researchers Feel Pressed to Deliver Favorable Results, BALT. Sun, June 26, 2001, at 1 A; see supra notes 72-76 and accompanying text; see also KENNEY, supra note 40, at 55-72.

103. Id. at 55-72.

104. See Eisenberg, supra note 12, at 216-26; Krimsky, supra note 53, at 30; Joshua A. Newberg \& Richard L. Dunn, Keeping Secrets in the Campus Lab: Law, Values, and Rules of Engagement for Industry-University R\&D Partnerships, 39 Aм. Bus. L.J. 187, 201-12 (2002). 
their research methods and results. ${ }^{105}$ They attribute this change in the traditional academic culture of openness during ongoing research to the concern with preserving patent rights and with corporate funding conditions of confidentiality prior to publication of research results. ${ }^{106}$ Faculty also describe the contrast between academic values that emphasize giving credit to prior work of other researchers, in the tradition of Newton's statement that he was able to see farther by "standing on ye sholders of Giants," and the patent application process, which requires the researcher to distinguish the research discovery from others. ${ }^{107}$ Relationships may also change between faculty and graduate students, whose value as cheap labor in the search for profitable research discoveries conflicts with an academic tradition of faculty mentorship of Ph.D. students in the discipline. ${ }^{108}$

Changes in the research process also include what faculty do with their research results. Within a traditional academic culture, faculty reputation has been largely based on being the first to publish research results in scholarly journals in the public domain. ${ }^{109}$ By participating in the patent process, faculty instead engage in the restriction of the public domain. Further, the insertion of the university technology transfer office and corporate funders into the research process delays publication during the patent application process, which may include prior corporate review to determine a corporate funder's interest in covering patent application costs or in anticipated licensing rights. While the costs of patents to the public domain are generally justified as encouraging individuals to invest the time and

105. See KenNeY, supra note 40, at 108-11, 121-31; Blumenthal et al., supra note 71, at 372-73; Eisenberg, supra note 91, at 1375; Jonathan King \& Doreen Stabinsky, Patents on Cells, Genes, and Organisms Undermine the Exchange of Scientific Ideas, Chron. Higher Educ., Feb. 5, 1999, at D6; see also Jordan Paradise, European Opposition to Exclusive Control Over Predictive Breast Cancer Testing and the Inherent Implications for U.S. Patent Law and Public Policy: A Case Study of the Myriad Genetics' BRCA Patent Controversy, 59 Food Drug L.J. 133, 149 (2004) (discussing the negative impact on researchers of the decreased sharing of basic data).

106. See KENNEY, supra note 40, at 108-11, 121-31; Blumenthal, et al., supra note 71, at 368, 37273; David Blumenthal et al., University-Industry Research Relationships in Biotechnology: Implications for the University, 232 SCIENCE 1361, 1361-66(1986); Eisenberg, supra note 91, at 1375; Krimsky, supra note 53, at 29-31; Birch \& Cohn, supra note 102.

107. Lawrence M. Sung, Collegiality and Collaboration in the Age of Exclusivity, 3 DePaul J. Health Care L. 411,417 n. 17, 436-38 (2000) (citing Robert Merton, On the Shoulders of Giants: A Shandean Postscript 31 n.3 (1965) (quoting Letter from Sir Isaac Newton to Robert Hooke (Feb. 5, 1765 or 1676)); see Kathryn Packer \& Andrew Webster, Patenting Culture in Science: Reinventing the Scientific Wheel of Credibility, 21 Scr. Tесн. \& Hum. Values 427 (1996).

108. See KenNeY, supra note 40, at 88, 117-18.

109. See Rai, supra note 12, at 92. 
expense necessary for the risky work of invention, such a rationale does not apply to academic research. A patent owner's monopoly rights during the patent period create an incentive to invent and disclose the owner's inventions to the public. ${ }^{110}$ Faculty already have an incentive to invent and disclose without the need for patent incentives based on the communal values of science and the professional structure of the university that judges faculty merit largely on the basis of their research and publications. "II These professional incentives have been highly successful, as evidenced by the intense competition among academic scientists to be the first to publish their research results and methodology. ${ }^{112}$

\section{National Consequences of Privatization and Commercialization of Academic Research}

The public mission of public or private nonprofit universities describes the social role of academia to serve the public interest, which requires university and faculty independence from conflicting interests of either government or private parties. The university's public mission, though, also provides a common ground with the social role of the government to serve the public interest. Similar to public funding of governmental services, public subsidies to nonprofit corporations reflect a public policy of encouraging nonprofit corporations to provide certain types of goods and services for the public welfare, rather than for profit. ${ }^{113}$ As nonprofit corporations, universities receive public subsidies designed to support and maintain their efforts to provide education in the public interest. ${ }^{114}$ In this way, the

110. See Eisenberg, supra note 45, at 1668. As of 1995, the U.S. patent term is 20 years from the date of filing the patent application; prior to 1995, the term was 17 years from the date of issuance of the patent. Robert L. Harmon, Patents and the Federal Circuit 4-5 (5th ed. 2001); Dale H. Hoscheit \& Lisa M. Hemmendinger, 2000 Cumulative Supplement, in Kenneth J. Burchfiel, Biotechnology and the Federal Circuit 137 (Supp. 2000).

111. See Eisenberg, supra note 12, at 183-84; Rai, supra note 12, at 88-94.

112. See Rai, supra note 12 , at 119-20.

113. See Lester M. Salamon, America's Nonprofit Sector: A Primer 7-32 (1992), discussed in Barbara K. Bucholtz, Reflections on the Role of Nonprofit Associations in a Representative Democracy, 7 Cornell J.L. \& Pub. Pol'y 555, 565-68 (1998); Martha Minow, Partners, Not Rivals?: Redrawing the Lines Between Public and Private, Non-Profit and Profit, and Secular and Religious, 80 B.U.L. Rev. 1061, 1083-85 (2000); Peter D. Blumberg, From "Publish or Perish" to "Profit or Perish": Revenues From University Technology Transfer and the \$501(c)(3) Tax Exemption, 145 U. PA. L. Rev. 89, 101-105 (1996); John D. Colombo, Why is Harvard Tax-Exempt? (And Other Mysteries of Tax Exemption for Private Educational Institutions), 35 ARIz. L. Rev. 841, 857-77 (1993).

114. Education is the second largest nonprofit service employer in the United States. Burton A. Weisbrod, The NonProfit Economy 72 (1988). 
university's institutional independence is similar to other private nonprofit organizations, which receive public subsidies under U.S. law through public funding, federal corporate income tax exemption, federal tax deductibility of donations, ${ }^{115}$ and state sales tax and property tax exemptions, ${ }^{116}$ on the condition that they fulfill their public interest goals. ${ }^{117}$ Traditional policies and practices of academic freedom-including faculty autonomy and independence-have been integral to ensuring that faculty work can further the university's social role. ${ }^{118}$

The privatization of academic research through university patenting and licensing activities has important repercussions for the public. Prior to the BayhDole Act, publicly funded academic research results generally became part of the public domain, a practice that was consistent with the university's public mission and with the logic that publicly subsidized research belongs to the public. The federal government held the title to federally funded research discoveries, which were either placed directly into the public domain or were made widely available to the public through nonexclusive licensing to government patents. ${ }^{119}$ Such publicly funded research results in the public domain were successfully used by industry in further research and development $(R \& D)$ that eventually led to patented products. For example, an internal NIH study shows that publicly funded academic basic research was instrumental in pharmaceutical corporations' development of five top selling drugs worldwide in 1994 and 1995, including Zantac (to treat ulcers), Vasotec (to treat hypertension), and Prozac (to

115. Nonprofit private universities qualify for such exemptions as 501(c)(3) organizations, under 26 U.S.C. $\$ 501$ (c)(3), serving educational purposes. Blumberg, supra note 113, at 101-05; see also Bucholtz, supra note 113, at 560-61; Colombo, supra note 113, at 857-77 (discussing the theories underlying tax exemptions).

116. Blumberg, supra note 113, at 91-92; Bucholtz, supra note 113, at 561-62; Colombo, supra note 113 , at $855-56$.

117. For an excellent discussion of a policy proposal to deny the 501(c)(3) tax exemption to university-industry licensing agreements that are inconsistent with the public purpose basis for the tax-exempt status, see Blumberg, supra note 113, at 134-46.

118. See supra notes $22-30$ and accompanying text.

119. In some agencies, a university or other government contractor could petition the federal agency to shift title from the government to the contractor. Eisenberg, supra note 45, at 1683-84, 1691-92. See supra text accompanying note 46. 
treat depression). ${ }^{120}$ These drugs were developed and patented in the 1970 s by pharmaceutical companies, ${ }^{121}$ which drew heavily from U.S. publicly funded academic research discoveries in the public domain and from publications by academic researchers in other countries. ${ }^{122}$

By authorizing patents on federally funded research, Bayh-Dole encouraged universities to restrict the public domain by establishing private ownership and control of academic research. With exclusive licensing by industry of university-owned patents, this private control becomes monopoly corporate control over publicly funded research during the twenty-year patent period. ${ }^{123}$ The patenting and exclusive licensing of publicly funded research imposes multiple costs on the public: through public funding of the academic research; ${ }^{124}$ through the restriction of the public domain with patents and licenses that impede access to research results; ${ }^{125}$ through the university's service of private rather than public interests; ${ }^{126}$ and again through paying monopoly prices for goods owing to exclusive licensing of university-owned patents, as well as the private corporations' patents on the end products. ${ }^{127}$ Examples include the University of Minnesota's exclusive license of its patent on carbovir, which resulted from NIH-funded research, to the pharmaceutical corporation GlaxoSmithKline, which used carbovir to develop the antiretroviral drug abacavir sulfate, marketed under the brand name Ziagen. ${ }^{128}$ Ziagen is a very profitable drug,

120. Rx RED Myths: The Case Against the Drug Industry's R\&D "Scare Card", Cong. RePort, app. c (Public Citizen Congress Watch), July 2001, available at http:/www.citizen.org/documents/ rdmyths.pdf (last visited Oct. 4, 2004) [hereinafter $R x R \& D M y t h s]$. Public Citizen's Congress Watch obtained this NIH report through a Freedom of Information Act (FOIA) request. The five drugs studied sold $\$ 1$ billion or more in 1994 and 1995 . Id. Zantac costs about $\$ 100$ for 60 pills; Vasotec costs about $\$ 135$ for 60 pills; and Prozac costs about $\$ 75$ for 30 pills. Drug Industry Gets Significant Help from U.S. Taxpayers, Report Says, Associated Press, July 23, 2001.

121. Rx R\&D Myths, supra note 120, at 7. The pharmaceutical corporations included Glaxo, Burroughs Wellcome, Merck, Squibb, and Eli Lilly. Id. at 14, 20, 27, 33.

122. Id. at 7 . The five drugs "were conceived through research conducted in the $1950 \mathrm{~s}$, " $60 \mathrm{~s}$ and early "70s." $I d$.

123. See supra notes $65-76$ and accompanying text.

124. Eisenberg, supra note 45, at 1666; Lieberwitz, supra note 32.

125. See supra notes $94-100$ and accompanying text.

126. See supra notes 69-83, 92-94 and accompanying text.

127. Eisenberg, supra note 45, at 1666-69; Lieberwitz, supra note 92, at 782; Lieberwitz, supra note 32.

128. Peter Ritter, Bitter Pills, City Pages, July 4, 2001, at http://www.citypages.com/databank/22/ 1074/article9665.asp (last visited Oct. 5, 2004). 
with predicted annual sales of up to $\$ 800$ million, including royalties of 5 to 10 percent of sales going to the University of Minnesota. ${ }^{129}$ Publicly funded researchers at Yale University discovered the application of Stavudine (d4T) as an antiretroviral AIDS treatment. ${ }^{130}$ Yale exclusively licensed its patent on Stavudine to the pharmaceutical corporation, Bristol-Myers Squibb, which sells the drug under the brand name Zerit ${ }^{131}$ for an average price of $\$ 8.56$ for the dose of two $40 \mathrm{mg}$ tablets. ${ }^{132}$ Yale profited from the sales, earning at least $\$ 261$ million in royalties between 1994 and 2000. ${ }^{133}$

The multiple costs to the public of patenting and licensing of academic research apply to corporate funding as well. A conflict exists between public and private interests where corporate funding is the quid pro quo for exclusive corporate licensing of university-owned patents. ${ }^{134}$ Like the patenting and exclusive

129. Id. University of Minnesota's share of a lump sum of $\$ 7.5$ million, plus royalties of between $5-10 \%$ of sales was the result of a settlement agreement that resolved a patent infringement suit by the university against GlaxoSmithKline. Id.

130. Ellen F. M. 't Hoen, The Responsibility of Research Universities to Promote Access to Essential Medicines, 3 Yale J. Health Pol'y L. \& Ethics 293, 294-95 (2003); Tina Rosenberg, Look at Brazil, N.Y. Times MAG., Jan. 28, 2001, at 31, 52, available at http:/www.nytimes.com/library/magazine/ home/20010128mag-aids.html (last visited Oct. 5, 2004); Philippe Demenet, The High Cost of Living, Le Monde Diplomatrque, Feb. 4, 2002, available at http://mondediplo.com/2002/02/ 04stavudine (last visited Oct. 5, 2004).

131. 't Hoen, supra note 130, at 294-95.

132. See Demenet, supra note 130. In South Africa, Bristol-Myers Squibb charged $\$ 2.23$ per dose, which most people could not afford. Id.

133. Id. A nother example of publicly funded academic research leading to discovery of an essential medicine is the anti-HIV drug T-20, patented by Duke University and marketed by Roche under the brand name Fuzeon for about $\$ 20,000$ per year in the United States. See Consumer Project on Technology, at http://www.cptech.org/ip/health/aids/t20/(last visited Dec. 29, 2004).

134. See Lieberwitz, supra note 32; Lieberwitz, supra note 92, at 789. An external evaluation of the large-scale corporate funding agreement between University of California at Berkeley and Syngenta concluded that universities should avoid such agreements, due to the conflict of interests created within the university. See Lawrence Busch et al., External Review of the Collaborative Research Agreement between Novartis Agricultural Discovery Institute, Inc. and the Regents of the University of California (2004), available at http://www.berkeley.edu/news/media/releases/2004/07/ external_novartis_review.pdf; Rex Dalton, Biotech Funding Deal Judged To Be 'a Mistake' for Berkeley, 430 Nature 598 (2004) (noting the unusual nature of the Berkeley-Syngenta agreement in funding an entire academic unit, rather than funding specific researchers or scientific research groups); Goldie Blumenstyk, Reviewers Give Thumbs Down to Corporate Deal at Berkeley, Chron. Higher Educ., Aug. 6, 2004, at A25 (quoting the external evaluation report's criticism of the agreement provision of Syngenta's first rights to exclusive licenses on inventions by participating faculty members, even if their work had been federally funded: "Such an occurrence strains conventional thinking on the proper stewardship of public funds[.]"). See supra notes 76, 102 and 
licensing of publicly funded research, the industry-university exchange of research funds for monopoly control over patents restricts the public domain of academic research. As in the case of publicly funded research, this universityindustry relationship favors private commercial interests over the traditional public interest goal of the university. By patenting academic research discoveries and selling the rights to use the patents, universities substitute their own financial interests for the public interest. Furthermore, by entering exclusive licensing agreements, universities also serve the private financial interests of the exclusive licensees. Even if the university broadens access to its patents through nonexclusive licensing of its patents, the private ownership and marketing of the academic research still conflicts with the public mission of the university, which requires academic research that is independent of private financial interests. ${ }^{135}$

The commercialization of academic research may well reduce both the scope and quality of the research. The growth of university practices modeled on for-profit businesses, including priorities on commercially viable research, protection of private ownership rights of intellectual property, and increases in secrecy, undermines the communal academic culture that encourages innovation and experimentation. ${ }^{136}$ The focus on profit potential of research may encourage short-term applied research rather than longer-term theoretic research. ${ }^{137}$ Studies have reported that corporately financed researchers are significantly more likely than researchers who are not funded by the corporation to reach favorable results concerning a corporation's product, including pharma-

accompanying text. Michigan State University sociology professor Lawrence Busch, who headed the evaluation group, separately described the corporate funding agreement as creating the impression that the academic department was "biased toward the funding source," stating that "[u]niversities as institutions can only be objective observers on the scientific and regulatory scene to the extent that some distance remains between them and industry funding sources." Blumenstyk, supra.

135. On the relationship between university independence and its institutional legitimacy, see Sheila Slaughter \& Larry Leslie, Academic Capitalism: Politics, Policies, and the Entrepreneurial University (1997); Capitalizing Knowledge: New Intersections of Industry and Academia (Henry Etzkowitz et al. eds., 1998).

136. See Michael R. Taylor \& Jerry Cayford, American Patent Policy, Biotechnology, and African Agriculture: The Case for Policy Change, 17 Harv. J.L. \& Tech. 321, 342-43 (2004); Julia Porter Liebeskind, Risky Business: Universities and Intellectual Property, Academe, Sept.-Oct. 2001, at 49, 49-52, available at http://www.aaup.org/publications/Academe/2001/01SO/so01lie.htm; supra notes 105-108 and accompanying text.

137. Keeping Science Open, supra note 66, at v. 
ceutical products. ${ }^{138}$ Some pharmaceutical companies have commissioned university professors to write an article, which is then ghostwritten by an employee of the drug company or medical marketing company and submitted to the professors for their approval prior to submission to a medical journal. ${ }^{139}$ There have been incidents, as well, of corporate funders placing strong pressure on faculty researchers to suppress research results that go against the corporation's economic interests. For example, University of California, San Francisco researcher James Kahn was pressured by corporate funder Immune Response Corporation to alter his negative clinical trial results of the company's HIV vaccine. ${ }^{140}$ When Kahn refused, Immune Response sued him. ${ }^{141}$

Conflicts of interest have led to justified concerns about the objectivity of faculty researchers and the reliability of research studies. The scientific journals Nature, the New England Journal of Medicine, the Journal of the American Medical Association, and the Lancet, now require that authors of articles accepted for publication "submit sources of funding, records of employment, and histories of financial investments." ${ }^{142}$ Readers will also be informed of an author's refusal to disclose this information. ${ }^{143}$ These journals are considering requiring corporations to publicly register all drug trial results as a condition to publishing any specific trial results. ${ }^{144}$

138. Press \& Washburn, supra note 40, at 42; Mildred K. Cho \& Lisa A. Bero, The Quality of Drug Studies Published in Symposium Proceedings, 124 Annals Internal Med. 485 (1996); Mark Clayton, Corporate Cash Campus Labs, Christian Sci. Monitor, June 19, 2001, at 11; Krimsky, supra note 53, at 34; Bekelman et al., supra note 80, at 456.

139. Melody Petersen, Madison Ave. Has Growing Role in the Business of Drug Research, N.Y. Times, Nov. 22, 2002, at Al (noting that "[a] 1998 survey of named authors writing for some of the nation's top journals, including The Journal of the American Medical Association, which published the survey, found that 11 percent of the articles had been ghostwritten.").

140. Ritter, supra note 128.

141. Id.; see also Press \& Washburn, supra note 40, at 42 (describing a case in 1996 where four university science researchers resigned after their corporate sponsor, Sandoz [now Novartis], altered a manuscript to remove findings of potential negative effects of the corporation's drugs: "The researchers aired their concerns in a letter to the Journal of the American Medical Association: 'We believed that the sponsor... was attempting to wield undue influence on the nature of the final paper. This effort was so oppressive that we felt it inhibited academic freedom."').

142. Kathleen Huvane, Researchers Required to Show Money Trail, World Watch, Jan.-Feb. 2002 , at 7 .

143. Id.

144. Barry Meier, Glaxo to Begin Posting Drug Trial Results, N.Y. Times, Sept. 1, 2004, at C2; Barry Meier, A.M.A. Adds Its Voice to Call for Disclosure on Drug Trials, N.Y. TIMEs, June 16, 2004, at C1. 
A less tangible, but essential, measure of the impact of universities' market activities is the potential reduction of the public trust that universities are fulfilling their public mission rather than pursuing private economic interests. A recent decision from the Federal Circuit expressed skepticism that universities with active technology transfer programs can plausibly present themselves as pursuing purely scholarly activities. In Madey v. Duke University, ${ }^{145}$ the Federal Circuit refused to apply the common law patent "experimental use exemption" ${ }^{146}$ to Duke's use of patented laser technology in its regular "business" of research in its physics department. The court found no basis for applying the narrow experimental use exemption more liberally to nonprofit institutions, such as Duke University, than to for-profit businesses. ${ }^{147}$ In dicta, the court implied its skepticism of Duke's attempt to claim the experimental use exemption while simultaneously "pursuing an aggressive patent licensing program from which it derives a not insubstantial revenue stream." ${ }^{148}$ With this statement, the court expresses the view that Duke - and other universities-are institutionally indistinguishable from for-profit corporations in pursuing their private economic interests. ${ }^{149}$

\section{Global Implications of the Corporate University}

Viewing the issues of university privatization and commercialization from a global perspective reveals the impact of U.S. national policy and multilateral trade policy on other countries-particularly on developing countries. The

145. 307 F.3d 1351 (Fed. Cir. 2002), cert. denied, 539 U.S. 958 (2003).

146. Plaintiff Madey sued Duke University for patent infringement based on Duke's use of Madey's patented laser technology in the Duke physics department. Madey had been a tenured professor in the Duke University physics department. After Duke removed him from the position of director of the free electron laser lab, Madey resigned from the faculty. Duke continued to use Madey's patented laser technology. Id. at 1352-53. The district court had held that the common law "experimental use" exemption immunized from patent infringement liability Duke's use of the patented laser technology "solely for research, academic or experimental purposes." Id. at 1355.

147. Id. at 1362-63. The circuit court emphasized that the experimental use exemption is a narrow, judicially created exemption from enforcement of patent infringement claims, covering only research carried out merely "for amusement, to satisfy idle curiosity, or for strictly philosophical inquiry." Id. at 1362 (quoting Embrex, Inc. v. Serv. Eng'g Corp., 216 F.3d 1343, 1349 (Fed. Cir. 2000)).

148. Id. at 1362-63 n.7.

149. See Lieberwitz, supra note 92, at 786; Rebecca S. Eisenberg, Patent Swords and Shields, SCIENCE, Feb. 14, 2003, at 1018, 1019. 
Bayh-Dole Act is explicit in its goal of providing a competitive market advantage to U.S. industry. ${ }^{150}$ Where federal funds have been granted to a non-U.S. contractor, the Bayh-Dole Act authorizes the funding agreement to withhold from that non-U.S. contractor the right to retain title to an invention. ${ }^{151}$ The Bayh-Dole Act requires private patent owners on federally funded inventionswhich would include universities - to give preference on exclusive licenses to businesses that will use the licenses to manufacture the invention substantially in the United States. ${ }^{152}$

An international perspective also brings into relief the ideological underpinnings of the Bayh-Dole Act policy of encouraging the commercialization of publicly funded research discoveries. This strong favoring of private ownership of intellectual property--including publicly funded research-reflects an ideology that places private property and markets at the center of public policy, viewing patents as a "natural right," 153 in contrast to an ideological view of intellectual property rights more as a privilege, which is socially constructed. ${ }^{154}$ Under a natural rights approach, protecting patents is the goal of public policy. In contrast, under a "social construction" approach, the goal of public policy is defined first, followed by a determination of whether patents will promote the public policy goal. Several examples illustrate the difference between viewing patents

150. See Rebecca S. Eisenberg, A Technology Policy Perspective on the NIH Gene Patenting Controversy, 55 U. Pitt. L. Rev. 633, 636 (1994).

151. 35 U.S.C. $\S 202(1980)$.

152. 35 USC $\$ 204$ (1980); see also Eisenberg, supra note 150, at 650.

153. See Susan K. Sell, TRIPS and the Access to Medicines Campaign, 20 W Is. IN.r'L L.J. 481, 486 (2002). Sell notes that even the U.S. courts did not take a natural rights, pro-patent approach to intellectual property until the early to mid-1980s, which was also the first time the courts stopped referring to patents as monopolies. Prior to this period, U.S. legislative and judicial policy viewed patents with suspicion, given their anti-competitive effects. Id. at 489-90.

154. See Keeping Science Open, supra note 66, at 1,7-8; Sell, supra note 153, at 496-97. This view of patents as a privilege describes the patent systems in Europe, "granted at the discretion of governments in pursuit of economic, social, or technological objectives." Keeping Science Open, supra note 66, at 7-8. This approach is consistent with the broader exclusions of patentable subject matter in European patent systems and the application of a standard of "public order" or morality to determine patentability. Id.; see Margo A. Bagley, Patent First, Ask Questions Later: Morality and Biotechnology in Patent Law, 45 WM. \& MARY L. Rev. 469, 476, 485-95, 517-28 (2003) (discussing the lack of a statutory criterion of morality in U.S. patent law and the demise of the judicial doctrine of "moral utility" following the 1980 Supreme Court decision in Diamond v. Chakrabarty, 447 U.S. 303 (1980), in contrast to the express consideration of morality in the European Union, including the Convention on the Grant of European Patents and the European Union Biotechnology Directive). 
as a goal or as a means. The first example concerns the problem of adherence to therapy in AIDS treatment, which is made more difficult when patients must take multiple pills. The major obstacle to combining three essential antiretroviral drugs into one pill lies in the patenting of these medications by different corporations, which are unwilling to cross-license their patents. ${ }^{155}$ In India and Thailand, which do not yet have patent protections on pharmaceuticals, some generic companies have been able to combine the three drugs into one pill. ${ }^{156}$ Thus, defining the goal as protecting patents excludes resolution of the health issue. In contrast, defining the goal as the successful treatment of disease leads to the conclusion that placing medical knowledge into the public domain is the appropriate means to reach the public health goal. ${ }^{157}$

Two examples highlight the importance of maintaining a focus on the public health goal to find the most effective means to provide universal access to medicines. UNICEF's highly successful global vaccination campaign achieved a vaccination rate of over 80 percent. ${ }^{158}$ In Brazil, considered a developing country, the government has made the decision to deliver free AIDS treatment to all patients who cannot afford the medication. ${ }^{159}$ The means chosen to achieve this goal is the manufacture of generic drugs at a fraction of the cost of patented drugs, which has lowered the price of medication by at least 79 percent. ${ }^{160}$ In contrast, the Bayh-Dole Act and U.S. patent law, which take a "natural rights" approach equating private property and the market with public policy, ignore those left out of market transactions and exclude the consideration of ethical and moral grounds in determining the proper content and scope of legal property rights. ${ }^{161}$

Defining intellectual property rights as a goal rather than a means also encourages a narrowing of research agendas to emphasize commercial potential. ${ }^{162}$

155. Access to Essential Medicines, supra note 66, at 10.

156. Id.

157. See Sell, supra note 153, at 497 (discussing the possibility of reframing the TRIPS trade agreement as a public health issue).

158. Rosenberg, supra note 130.

159. Id.

160. Id. As Rosenberg notes, "Brazil's program almost certainly pays for itself. It has halved the death rate from AIDS, prevented hundreds of thousands of new hospitalizations, cut the transmission rate, helped to stabilize the epidemic and improved the overall state of public health in Brazil." Id.

161. See supra notes 153-154 and accompanying text.

162. See supra note 137 and accompanying text. 
Thus, the Bayh-Dole Act reinforces the problem of the production of "me too" drugs by pharmaceutical corporations, adding to the multiplicity of drugs that treat the same conditions or diseases in industrialized countries, ${ }^{163}$ while failing to engage in $\mathrm{R} \& \mathrm{D}$ of drugs and medical procedures to treat diseases, such as resistant strains of malaria and tuberculosis, sleeping sickness, and dengue fever, affecting people in developing countries. ${ }^{164}$

Patenting and licensing of research results, regardless of whether the research is publicly or privately funded, has particular global implications for developing countries. TNCs, with the United States as their strongest ally, have successfully defined intellectual property rights as "trade-related" issues subject to international trade agreements. ${ }^{165}$ WTO agreements include TRIPS, ${ }^{166}$ which was created in 1994 as part of the Uruguay Round of GATT (General Agreement on Tariffs and Trade), with the goal of harmonizing national laws on intellectual property rights. ${ }^{167}$ Under TRIPS, signatories to GATT have agreed to enact national laws that establish minimum substantive standards of intellectual property rights pro-

163. See 't Hoen, supra note 130, at 296-97 (discussing the concentration of $R \& D$ in industrialized countries and the statistics demonstrating that "[i]nvestments in health-related R\&D [tend] to gravitate towards illnesses or symptoms that offer the greatest potential return on investment, regardless of actual health needs."). In the United States, during the period of 1981-2000, "less than five percent of the drugs introduced by the top twenty-five pharmaceutical companies were therapeutic advances." Id. at 297. "t Hoen notes that "seventy percent [of the therapeutic advances] were developed with government involvement." Id.; see also Access to Essential Medicines, supra note 66 , at 2 .

164. 't Hoen, supra note 130, at 296-97. See also Médecins Sans Frontières Access to Essential Medicines Campaign and the Drugs for Neglected Diseases Working Group, Fatal Imbalance: The Crisis in Research and Development for Drugs for Neglected Diseases 4, 8, 11 (2001), available at http://www.msf.org/source/access/2001/fatal/fatal.pdf (last visited Jan. 25, 2004) (discussing the failure of private pharmaceutical companies to adequately address either "neglected diseases" [such as tuberculosis, and malaria] or "the most neglected diseases" [such as sleeping sickness, dengue fever, and leishmaniasis] in developing countries, the failure of governments in industrialized countries to provide adequate public funding directed to research on such diseases, and the need for a new nonprofit initiative to develop medicines to treat such diseases).

165. See Sell, supra note 153, at 485-87.

166. Agreement on Trade-Related Aspects of Intellectual Property Rights, Apr. 15, 1994, Marrakesh Agreement Establishing the World Trade Organization, Annex 1C, Legal InstruMents - Results of the URuguay Round vol. 31, 33 I.L.M. 81 (1994).

167. See Sell, supra note 153, at 481-91; Grace K. Avedissian, Global Implications of a Potential U.S. Policy Shift Toward Compulsory Licensing of Medical Inventions in a New Era of "Super-Terrorism," 18 A m. U. INT'L L. Rev. 237, 251-52, 262-69 (2002). See generally Frederick M. Abbott, TRIPS in Seattle: The Not-So-Surprising Failure and the Future of the TRIPS Agenda, 18 Berkeley J. INT'L L. 165 (2000) (discussing the lack of consensus among WTO members). 
tection, which include patent protection of pharmaceutical products, plant varieties, and computer programs. ${ }^{168}$ Developing countries were strongly pressured by powerful countries, particularly the United States, to agree to TRIPS, ${ }^{169}$ leading critics to define the TRIPS goal of "harmonizing" intellectual property rights laws as requiring adoption of "US-style intellectual property laws." TRIPS, developing countries are seriously restricted in their access to essential medicines, including AIDS drugs and other patented products. Without patent protections, these countries could create generic drugs (or other products), using technology and discoveries covered by the patents. Under TRIPS, however, they will be limited by the twenty-year patent term in creating generic products, ${ }^{171}$ with enormous financial impacts. ${ }^{172}$ For example, Bristol-Myers Squibb sold the patented antiretroviral drug, $d 4 T$, for more than $\$ 1,600$ per patient per year in South Africa; the generic form of this drug was sold in South Africa for $\$ 55$ per patient per year. ${ }^{173}$ Pfizer sells the patented drug Fluconazole, for treating cryptococcal meningitis, for \$14-25 per daily dose; the daily dose of the generic form of this drug costs seventy-five cents. ${ }^{174}$ The use of generic drugs to treat AIDS in Brazil has lowered the price of medicines by an average of 79 percent. ${ }^{175}$

168. Erin Donovan, Beans, Beans, the Patented Fruit: The Growing International Conflict over the Ownership of Life, 25 Loy. L.A. INT'L \& Comp. L. Rev. 117, 134-35 (2002); Srividhya Ragavan, Can't We All Get Along? The Case for a Workable Patent Model, 35 Ariz. ST. L.J. 117, 126-28 (2003). The Royal Society reports that "as of 1 January 2002, there were 144 Members of the WTO, accounting for over $90 \%$ of the world's trade." Keeping Science Open, supra note 66, at 3.

169. Sell, supra note 153, at 489, 493, 520; The Right to Good Ideas, Economist, June 23, 2001, at 21. The sources discuss the developing countries' resistance to TRIPS, but their eventual agreement in the hope of greater access to markets in OECD member countries; however, these economic commitments to the developing countries have not been fulfilled.

170. Lori Wallach, The Alphabet Soup of Globalization 4-5, available at http://www.citizen.org/ documents/alphabetpdf.PDF.

171. See Jonathan Michael Berger, Tripping Over Patents: AIDS, Access to Treatment and the Manufacturing of Scarcity, 17 Conn. J. InT'L L. 157, 183 (2002) (discussing TRIPS Article 33, which requires a minimum twenty year period of patent protection). See generally Martin J. Adelman \& Sonia Baldia, Prospects and Limits of the Patent Provision in the TRIPS Agreement: The Case of India, 29 VAND. J. TRANSNAT'L L. 507, 511 (1996) (analyzing the impact of TRIPS on the pharmaceutical industry in India).

172. See 't Hoen, supra note 130, at 296.

173. Access to Essential Medicines, supra note 66, at v.

174. Sell, supra note 153 , at 507 . The lowest price of a $200 \mathrm{mg}$ pill of fluconazole is 29 cents, manufactured by Cipla, an Indian generic firm; the highest price is from Pfizer in Guatemala at $\$ 29$ per 200mg pill. Access to Essential Medicines, supra note 66, at 1.

175. Rosenberg, supra note 130. 
Developing countries were able to negotiate for some concessions regarding the required dates of compliance with TRIPS, creating transition periods for developing countries until 2005, and for least developed countries until 2006, ${ }^{176}$ with this latter date recently extended until 2016. ${ }^{177}$ Developing countries also successfully negotiated the inclusion in TRIPS of some exceptions to the patenting requirements. Article 31 of TRIPS permits any WTO member country to issue compulsory licenses of patents to address national emergencies, enabling governments to license patents to domestic businesses to manufacture low-cost generic drugs in the face of national health crises, such as the AIDS epidemic, or in response to other national emergencies, such as global terrorism. ${ }^{178}$ The compulsory licensing exception is limited, however, to the manufacture of generic products for domestic use, which imposes a hardship on member countries without the infrastructure required to manufacture the generics. ${ }^{179}$ This Article 31 restriction, thus, creates barriers to the ability of member countries to export generic drugs to address the public health need in another country. ${ }^{180}$ In August 2003, a decision of the WTO General Council provided some flexibility in the implementation of Article 31, enabling member countries to export pharmaceutical products manufactured under a compulsory license to WTO member countries that do not have the capacity to manufacture the drugs. ${ }^{181}$ Article 30 ,

176. Avedissian, supra note 167, at 266-67. Prior to becoming “TRIPS-compliant," WTO members without patent protections on pharmaceutical products can still manufacture and export generic drugs to other countries. See id. at 262-64. The United States, however, has used "TRIPS-plus" mechanisms, such as bilateral treaties, to pressure developing countries to become TRIPS-compliant prior to the end of these transition periods. Sell, supra note 153, at 493, 500.

177. See Tara Kowalski, International Patent Rights and Biotechnology: Should the United States Promote Technology Transfer to Developing Countries?, 25 Loy. L.A. InT'L \& Comp. L. Rev. 41, 56 (2002). 178. Avedissian, supra note 167, at 262-64. Compulsory licensing is allowed under Article 31 for "antitrust violations, governmental use, and extremely urgent circumstances, including national emergencies." Id. at 262.

179. Id. at 265-66.

180. Id. at 265-66; Sell, supra note 153 , at 500 .

181. Developing countries had succeeded in placing this issue on the WTO's agenda, with the Doha Declaration of 2001, which instructed the WTO General Council to find a solution to the problem of the inability of some countries to effectively use compulsory licensing due to a lack of manufacturing infrastructure. See Avedissian, supra note 167, at $266 \mathrm{n} .150$ (discussing the WTO's Declaration on the TRIPS Agreement and Public Health, Fourth Ministerial Conference in Doha, Qatar, para. 6 (adopted Nov. 14, 2001)). The 2003 General Council's decision responds to the Doha Declaration by creating an interim waiver of the export restriction of Article 31, until 
which creates a "limited exception" to patenting requirements, may create an opening for a public health exception that permits such generic drug exports under compulsory licensing, ${ }^{182}$ although this remains a controversial interpretation. ${ }^{183}$ Another controversial area concerns "parallel importing" of patented drugs after they have been sold in another country, which may enable a member country to import the drugs at a discounted price without the patent holder's consent. ${ }^{184}$ Although TRIPS does not create any explicit restrictions on importing goods, pharmaceutical companies argue that their patent rights are not exhausted after the initial sale of the drug. ${ }^{185}$

Even with these important exceptions to patenting requirements, signatories to TRIPS could still be faced with litigation over patent infringements, including complaints filed under the dispute resolution processes of the WTO. ${ }^{186}$ Such disputes may concern disagreements over the scope of TRIPS exceptions, as well as disagreements over whether a country has fulfilled the difficult condi-

the TRIPS agreement is amended. See WTO, Implementation of Paragraph 6 of the Doha Declaration on the TRIPS Agreement and Public Health (Sept. 1, 2003), available at http://www.wto.org/ english/tratop_e/trips_e/implem_para6_e.htm (last visited Jan. 27, 2005); WTO, Doha Development Agenda: Decision Removes Final Patent Obstacle to Cheap Drug Imports (Aug. 30, 2003), available at http://www.wto.org/english/news_e/pres03_e/pr350_e.htm (last visited Jan. 27, 2005); Jennifer May Rogers, The TRIPS Council's Solution to the Paragraph 6 Problem: Toward Compulsory Licensing Viability for Developing Countries, 13 Minn. J. Global Trade 443, 457-61 (2004).

182. Avedissian, supra note 167, at 267-69. Article 30 states, "[WTO] Members may provide limited exceptions to the exclusive rights conferred by a patent, provided that such exceptions do not unreasonably conflict with a normal exploitation of the patent and do not unreasonably prejudice the legitimate interests of the patent owner, taking account of the legitimate interests of third parties." Agreement on Trade-Related Aspects of Intellectual Property Rights, supra note 166.

183. See Avedissian, supra note 167, at 267-69, 285 (noting that "developed countries are more likely to oppose the use of [Article 30] as the basis for permitring compulsory licensing for exports"); see also Sell, supra note 153, at 517-18 (discussing the action of European and American negotiators to block agreement, in the WTO Doha Declaration of 2001, that Article 30 could be used to justify generic drug exports as part of compulsory licensing under TRIPS).

184. Carlos M. Correa, Public Health and Patent Legislation in Developing Countries, 3 Tul. J. Tech. \& Intell. Prop. 1, 37-38 (2001); Allison Cychosz, The Effectiveness of International Enforcement of Intellectual Property Rights, 37 J. Marshall L. Rev. 985, 999-1000 (2004).

185. Correa, supra note 184, at 39-41.

186. See Ruth L. Okediji, Public Welfare and the Role of the WTO: Reconsidering the TRIPS Agreement, 17 Emory INT'L L. Rev. 819, 824 (2003) ("Dispute resolution in the WTO is unlikely to yield outcomes that disturb the strong presumption of protection for owners in a global marketplace."); Sell, supra note 153, at 492-94. 
tions to qualify for use of compulsory licenses. ${ }^{187}$ The United States has filed more WTO TRIPS complaints than all other member countries combined. ${ }^{188}$ Developing countries have also faced pressure from governments attempting to discourage their use of compulsory licensing and generic drug manufacturing. The United States has used its economic power to threaten trade sanctions or WTO complaints against Thailand, ${ }^{189}$ Brazil, ${ }^{190}$ and South Africa ${ }^{191}$ for their manufacture of generic versions of patented AIDS drugs. In response to such pressure, Thailand decided against compulsory licensing. ${ }^{192}$ It was only after well publicized political pressure from public interest groups in the "Campaign for Access to Essential Medicines"193 that the United States withdrew its threatened sanctions and complaints against Brazil and South Africa. ${ }^{194}$

\section{Social Implications of Privatization and Commercialization of Academic Research: Faculty Choices and Responsibilities}

Faculty cannot separate themselves from law and public policy, nor can they convincingly pretend that their work and their work process do not have social implications. Faculty choices about the content of their work and the nature of their work process are shaped in important ways by the values and norms ex-

187. See Okedjii, supra note 186, at 903-13 (discussing the use of the WTO dispute resolution process in a dispute involving the interpretation and application of TRIPS Article 30 and compulsory licensing); Berger, supra note 171, at 183-84 (discussing the use of the WTO dispute resolution process to address the meaning of the term "exceptions" under TRIPS).

188. Sell, supra note 153, at 492 (discussing the U.S. aggressiveness in filing fifteen complaints).

189. Id. at 500-01. In 1997 and 1998, the United States threatened trade sanctions against Thai exports in retaliation against Thailand's plan to produce a generic version of an AIDS drug. Id. at 500 .

190. Id. at 495-96 (discussing U.S. trade sanctions against both Argentina and Brazil and the U.S. WTO complaint against Brazil's law permitting compulsory licensing).

191. Id. at 500-04 (discussing the U.S. pressure upon South Africa, based on the South African Medicines and Medical Devices Regulatory Authority Act, that provided for compulsory licensing and parallel importing of patented AIDS drugs).

192. Id. at 500 .

193. Public interest organizations in the campaign include Médecins Sans Frontières, the Consumer Project on Technology, ACT UP, and Oxfam UK. Id. at 495-99, 502, 506-07, 510.

194. See id. at 495-96, 501-04. Developing countries' plans to issue compulsory licenses and the activism by the "Campaign for Access to Essential Medicines" have also helped motivate the large pharmaceutical corporations to avoid the impact of generic drug pricing by discounting the prices of AIDS drugs in developing countries. See Rosenberg, supra note 130; Sell, supra note 153, at 495, 510-13. 
pressed in the law. ${ }^{195}$ The national policy enacted in the 1980 Bayh-Dole Act, favoring privatization and commercialization of intellectual property, has led to major changes in the relationship between the university and the market and, as a result, has changed the relationship between the university and the public. Faculty are directly implicated in these changed social relations. By engaging in the patent application process throughout the world, by sharing in the commercial profits of marketing the patents, by acting simultaneously as academics and private entrepreneurs, and by entering close relationships with industry, faculty promote private market interests - their own, the university's, and industry's. Further, through their exclusive licensing agreements with for-profit corporations, universities assist for-profit corporations to use academic research to develop products marketed at monopoly prices. The social implications of these actions have global reverberations, particularly severe for developing countries under TRIPS, as patents and exclusive licenses apply to both basic and applied research, including upstream research tools and medicines essential to treating life-threatening diseases such as AIDS. The global effects apply to academic research in Europe as well, where patents and licenses are increasing and where industry has sought to change European patent law to reflect the broad definition of patentable subject matter used in U.S. law. ${ }^{196}$

Given the close interaction between law and the social role of the university, therefore, faculty should directly address the social implications of their work. This active engagement with public policy has roots in the 1915 founding of the AAUP, where faculty directly confronted the social role of faculty and the university. ${ }^{197}$ In their demands for academic freedom, faculty emphasized the importance of the university's public interest mission and the essential nature of faculty autonomy and independence in fulfilling this public mission. Current social and economic conditions make it as important for today's faculty to directly address the societal mission of the university and the faculty's work within the

195. See Susan S. Silbey \& Patricia Ewick, The Architecture of Authority: The Place of Law in the Space of Science, in THE Place of Law 75, 78 (Austin Sarat et al. eds., 2003) (discussing, in the context of the creation of university science laboratories, the way "that law and science collaborate in a mutual constitution whereby each is transformed, and the authority of each is preserved and extended."). The authors continue: "The interaction between law and science ends up recreating the world, not only materially but also culturally and morally." Id.

196. Keeping Science Open, supra note 66, at 7 (predicting that European law will not be changed in "the foreseeable future" to conform to U.S. patent law).

197. See supra notes 22-29 and accompanying text. 
university. This means that faculty, in the current context of privatization, should engage in debates about the changes in public policy that affect their work-including national laws such as the Bayh-Dole Act and multilateral trade agreements such as TRIPS. Such debates should address the university and faculty practices resulting from changes in public policy, including the effects of privatizing academic research through patenting and licensing and of closer university-industry relationships. These discussions should confront honestly the impact of privatization in multiple contexts: the changes in academic values, culture, and practice within the university; the impact of commercialization on the public interest; and the global effects of providing exclusive licenses to TNCs to use university-owned patents.

It is possible that these debates could result in endorsement by most faculty of the privatization and commercialization of academic research. It seems more likely, though, that full discussion of the issues will reinforce the fundamental importance of the university's public mission and faculty academic freedom, both of which are based on autonomy and independence from conflicting interests. If faculty find that privatization, implemented through the Bayh-Dole Act, SCAs, and TRIPS, threatens academic values, then they should act individually and collectively to oppose these measures.

Even in the current era of privatization and commercialization, individual faculty exercise a great deal of control over their research process and content, which includes choices about publication and patenting. Early faculty resistance to patenting as inconsistent with the traditional open culture of academic research can provide continued inspiration, ${ }^{198}$ including some well-known examples of faculty resistance to applying for patents. When asked who owned his polio vaccine, Dr. Jonas E. Salk is quoted as replying, "Well, the people, I would say. There is no patent. Could you patent the sun?" 199 Scientists Cesar Milstein and Georges Köhler decided not to patent their Nobel prize-winning invention

198. KeNNEY, supra note 40, at 32 (describing the "ideology... of scientists working for the public good" leading to the view that "industry's motives - especially that of profitability - were suspect, and the applied science orientation of industry was considered to be scientifically uninspiring to scientists").

199. Birch \& Cohn, supra note 102. Dr. Salk was apparently later influenced by the commercial biomedical explosion of the 1980s, for he applied for 7 patents on his therapeutic AIDS vaccine, Remune, and helped found a biotechnology company to develop it. Id.; see also Symposium, The Human Genome Project, DNA Science and the Law: The American Legal System's Response to Breakthroughs in Genetic Science, Panel One: Intellectual Property and Genetic Science: The Legal Dilemmas, 51 AM. U. L. Rev. 371, 377 (2002). 
of monoclonal antibody-producing hybridoma cells and requested that recipients of the cell line also not patent it. ${ }^{200}$ Professors Stanley Cohen and Herbert Boyer are reported to have initially resisted Stanford University's pressure to patent their 1973 groundbreaking invention of the Cohen-Boyer rDNA genesplicing technique, based on their concern about patenting basic research that had been built upon the prior research of other scientists. ${ }^{201}$ They agreed to apply for the patent, jointly owned by Stanford and University of California, but required that the university engage in non-exclusive licensing, with royalties going only to the university. ${ }^{202}$ Individual faculty continue to play a role in university decisions concerning patenting, as demonstrated by Yale University Pharmacology Professor William Prusoff's support of the Yale students' campaign to lower the cost of the AIDS drug d4T in South Africa. ${ }^{203}$ Yale owns the patent on d4T, which was developed by Professors Prusoff and Tai-shun Lin. ${ }^{204}$ Prusoff called for Yale University and its exclusive licensee Bristol-Myers Squibb to either waive their patenting and licensing rights and permit generic drug manufacturing or to supply the drug for free. ${ }^{205}$ Individual faculty also have a role to play in public policy deliberations, ${ }^{206}$ including expert testimony before congressional committees concerning the impact of patents and licensing on academic research. ${ }^{207}$

Given the strength of the trends toward commercialization of academic research, however, it will be difficult for faculty to have a sufficiently effective im-

200. Rai, supra note 12, at 94; Eisenberg, supra note 12, at n.8; KenNeY, supra note 40, at 129.

201. Rai, supra note 12, at 93-94; Dueker, supra note 41, at 493-94. Boyer did subsequently pursue commercial interests in 1976, as co-founder of the biotechnology company, Genentech, leading to his multi-millionaire status as a stockholder in the company. Krimsky, supra note 53, at 19.

202. Rai, supra note 12, at 93.

203. See Sell, supra note 153, at 511-12; Donald G. McNeil Jr., Yale Pressed to Help Cut Drug Costs in Africa, N.Y. Times, Mar. 12, 2001, at A3. Médecins Sans Frontières had initially asked Yale to waive its patent on $\mathrm{d} 4 \mathrm{~T}$. Id.

204. McNeil, supra note 203; Sell, supra note 153, at 511.

205. Sell, supra note 153, at 511-12; McNeil,supra note 203; Abigail Zuger, A Molecular Offspring, Off to Join the AIDS Wars, N.Y. Times, Mar. 20, 2001, at F7.

206. See 't Hoen, supra note 130, at 299-300 (describing a proposal by John Barton, Stanford University Professor of Law and Chair of the U.K. Commission in Intellectual Property Rights, for "a treaty to preserve the global scientific and technology commons.").

207. See, e.g., KeNNEY, supra note 40, at 84-85 (indicating that testimony was given at congressional hearings held in 1981). 
pact solely through individual choices and actions. ${ }^{208}$ Similar to their forebears in the early twentieth century, faculty in the early twenty-first century need collective action to protect their independence and autonomy. Such collective actions would reassert academic freedom as central to faculty identity, including maintaining independence from industry and contributing to the public interest. Even though legal issues such as intellectual property rights under the BayhDole Act and TRIPS may seem to be outside the expertise of most faculty, the values and policies underlying these legal matters so fundamentally affect faculty work, that it is essential to address them. Further, there are many collective actions that faculty can take to promote models of law and public policy that are consistent with values of academic freedom and the university's public mission. These actions can be done by faculty promoting changes in public policy and law, supporting changes in internal policy of their own universities, and forming alliances across universities.

In the sphere of governmental policy, faculty can provide collective support for their universities to lobby for changes in law and federal agency regulations that expand the public domain of research. Such reform efforts may range from full repeal of the Bayh-Dole Act to more specific reforms that significantly expand the public domain by amending the Bayh-Dole Act to strengthen the power of federal agencies to require public dissemination of federally funded basic research; ${ }^{209}$ to increase federal agencies' power to withhold title from government contractors or to require government contractors to issue nonexclusive licenses for use of their federally funded patents; ${ }^{210}$ or to give federal agencies the

208. See Robert P. Merges, Property Rights Theory and the Commons: The Case of Scientific Research, in Scientific Innovation, Philosophy, and Public Policy 145, 157-59 (Ellen Frankel Paul et al. eds., 1996) (discussing the difficulty of individual academic scientists adhering to the "community norm of nonproprietary open access" when their colleagues are engaged in patenting activities).

209. See Rai, supra note 12, at 148; Rai \& Eisenberg, supra note 51, at 59. In 1996, the National Human Genome Research Institute and the NIH announced this condition for large-scale human sequencing grants and, subsequently, for grants for research on single nucleotide polymorphisms (SNPs). Rai, supra note 12, at 147-48.

210. See Rai, supra note 12, at 151; Access to Essential Medicines, supra note 66, at 6 (discussing the NIH's efforts to broaden access to NIH-funded research through licensing provisions that call for nonexclusive licensing, reduced royalties for sales of drugs in developing countries, and licensee actions that benefit the public sector); Arno \& Davis, supra note 69 (proposing enforcement of governmental "march-in" rights under the Bayh-Dole Act to impose price controls on drugs developed fully or in part with federal funds). 
power to require government contractors to share basic research tools with each other. ${ }^{211}$ Accompanying these efforts to promote legislative reform, universities can lobby for increased public funds for research and development of advances in science and medicine, rather than relying only on for-profit corporate research and development to capitalize on academic research. Faculty could directly support such reform measures by testifying before congressional committees concerning the need to amend the Bayh-Dole Act, describing the conflict between the university's public mission and private economic interests, the negative impact on the communal culture of patenting and licensing, and the harm to academic research by restricting the public domain.

Faculty can also act collectively within their own universities to promote internal policies that limit the use of patents and exclusive licensing, emphasizing the importance for faculty and universities to choose policies and practices that promote the public interest. Given the tactical difficulty of persuading the university and many faculty of the need to cease all patents and exclusive licenses, it may be most feasible to identify specific areas where patents and exclusive licensing are inconsistent with the universities' public mission and with the values of autonomy and independence underlying academic freedom. Arguments against patenting and licensing of such research can rely, as well, on the particular ethical and moral problems of patenting life forms or of limiting access by the poor, in the United States and in other countries, to medicines. For example, faculty could collectively support university policies that prohibit patenting or exclusive licensing of upstream research ${ }^{212}$ or of essential medicines, such as the Harvard and Stanford policies against patenting the gene fragments known as ESTs and $\mathrm{SNPs}^{213}$ and Yale University's decision to waive its patent rights on the AIDS medicine d4T in South Africa. ${ }^{214}$ Faculty can also act collectively to pressure the university to condition its acceptance of corporate funding on provisions that in-

211. Rai, supra note 12, at 113,150-51; Mikhail, supra note 50, at 392-93 (citing National INSTItutes of Health, Report of the National Institutes of Health Working Group on ReSEARCH ToOLs (1998), available at http://www.nih.gov/news/researchtools/index.htm).

212. See Bok, supra note 60, at 142 (proposing, in the context of curbing excesses under the BayhDole Act, that "universities ... agree not to use exclusive licenses or other restrictions on the sharing of early-stage discoveries with other researchers").

213. Rai, supra note 12, at 112-13. Expressed sequence tags (ESTs) and single nucleotide polymorphisms (SNPs) are basic genetic research material. Id. at 104-05.

214. See supra notes 203-205 and accompanying text. 
crease faculty independence from corporate influence over their research agendas and that decrease the use of exclusive licensing agreements.

These collective actions will be more powerful if done by faculty forming alliances across universities. At the very least, faculty can share information about policies that restrict patenting and licensing in their universities, which can then be used as models in other universities. One example of an important alliance with global effects is "Universities Allied for Essential Medicines" (UAEM), which links universities in the United States, the United Kingdom, and Canada, to support faculty and student efforts to place pressure on the universities to waive their patent rights on AIDS medicines in developing countries. ${ }^{215}$ To be effective, such waivers must include both the university's waiver as patent owner and a waiver of rights by the exclusive corporate licensee. As a result of such a campaign, Yale University and its exclusive licensee, Bristol-Myers Squibb, waived their patent and licensing rights on the AIDS drug d4T in South Africa and Bristol-Myers Squibb decided to cut the price of $\mathrm{d} 4 \mathrm{~T}$ in South Africa to $\$ 0.15$ for a daily dose, which is $1.5 \%$ of the price in the United States. ${ }^{216}$ As part of the broader access to the essential medicines campaign, UAEM has played an important role in re-focusing attention onto the institutional mission of universities to serve the public interest. ${ }^{217}$

\section{Conclusion}

The politics of privatization have made their mark on the university, thrusting academic work directly into the controversies of globalization. With the Bayh-Dole Act of 1980, universities were encouraged to become market actors, patenting the results of federally funded research and licensing those patents to industry. These increased university-industry interactions were accompanied by

215. See Universities Allied for Essential Medicines, at http:/www.essentialmedicines.org/ about.html. Consider KeEPING Science Open, supra note 66, as an example of a report and recommendations by the Royal Society in the United Kingdom on issues such as limiting the scope of patents and increasing the use of compulsory licensing, which can form the basis for alliances among universities in different countries.

216. Sell, supra note 153, at 511-12; Zuger, supra note 205.

217. See Sell, supra note 153, at 495-97, 511-12 (discussing the success of the Access to Essential Medicines campaign, including the Yale University campaign, in responding to TRIPS with actions that "presented an alternative framing of [intellectual property] as a public health issue, not a trade issue." Id. at 497.); Access to Essential Medicines, supra note 66, at iii-v, 2-4. 
a growing trend of private corporate funding to universities conditioned on increased corporate control over distribution of funds and exclusive licenses on resulting university-owned patents. The university's identity as market actor was eased and reinforced by two additional developments in science and in politics. The discoveries of genetic engineering in the mid-1970s opened the door to commercialization of the new biomedical field of research, with the ability to imagine the applications of basic research at an earlier stage than ever before. In tandem with the biotechnology revolution, the Supreme Court laid the groundwork for the proliferation of patents in the life sciences, with the 1980 Chakrabarty decision, holding that "human-made" life forms can be patented. ${ }^{218}$ On the heels of the Supreme Court's decision, the newly created Federal Circuit Court of Appeals launched its pro-patent jurisprudence, creating fertile ground for patents on the new discoveries in genetics and biotechnology, including patents on basic research tools.

University privatization and commercialization have had negative consequences for academic culture and the public interest. The basic principles of academic freedom, which depend on faculty autonomy and independence from conflicting interests, have been compromised by the consideration of the commercial potential of academic research. Faculty relations and research agendas have been affected by commercial interests and corporate involvement in research. Patents and exclusive licenses have restricted the public domain, harming academic work and the public interest by creating impediments on further research and enabling corporate licensees to engage in monopoly pricing. The university's institutional legitimacy and the faculty's role in furthering the university's public mission have been undermined by the conflict of interests created by the multiple university-industry and faculty-industry economic relations. The interweaving of university, faculty, and corporate interests has broad effects as the patenting and licensing of academic research enters national and international markets. The global impact of patents and exclusive licensing of academic research has been amplified by multilateral agreements, such as TRIPS, which support transnational corporate interests by imposing and enforcing legal standards of intellectual property rights on WTO members, including developing countries.

218. Chakrabarty, 477 U.S. 303, 305, 309-10 (1980). 
In the face of these economic and social developments, faculty have important choices about their work and their identity. The strong professional norms of academic freedom continue to provide a solid foundation for individual and collective actions by faculty to oppose privatization and commercialization of the university. Individual faculty autonomy over research agendas, research process, and publication presents faculty with opportunities to seek broad public dissemination of their research methods and results and to resist pressures to patent their research results. Collective actions by faculty will also be essential given the current force of privatization and commercialization trends. In their own universities and through alliances across universities, faculty can collectively shape university policies and practices that further public interest goals, including university policies limiting the research that will be patented or exclusively licensed and university waivers of their existing patent rights. Faculty can also support university efforts to seek legislative reform that returns publicly funded research to the public domain. Through such actions, faculty recognize the social implications of their academic work and their individual and collective power to shape public policy and university practice. 